\title{
Asymmetric Effects of Remittances on Economic Growth in Nigeria: Evidence From Non-linear ARDL Analysis
}

\section{David Oluseun Olayungbo}

Obafemi Awolowo University Faculty of Social Sciences

Clement Olalekan Olaniyi ( $\sim$ richclemento@gmail.com )

Obafemi Awolowo University Faculty of Social Sciences https://orcid.org/0000-0003-0758-4830

Titus Ayobami Ojeyinka

Obafemi Awolowo University Faculty of Social Sciences

\section{Research}

Keywords: Remittances, Economic growth, Non-linear ARDL, Asymmetric effects, Nigeria

Posted Date: December 15th, 2020

DOl: https://doi.org/10.21203/rs.3.rs-126145/v1

License: (1) (i) This work is licensed under a Creative Commons Attribution 4.0 International License.

Read Full License 
Asymmetric effects of remittances on economic growth in Nigeria: Evidence from non-linear ARDL Analysis

David Oluseun, Olayungbo

Department of Economics,

Obafemi Awolowo University,

Ile-Ife, Nigeria

doolayungbo@oauife.edu.ng

$\&$

Clement Olalekan, Olaniyi*

Department of Economics,

Obafemi Awolowo University,

Ile-Ife, Nigeria

richclmento@gmail.com

coolaniyi@oauife.edu.ng

coolaniyi@mtu.edu.ng

$\&$

Titus Ayobami, Ojeyinka

Department of Economics,

Obafemi Awolowo University,

Ile-Ife, Nigeria.

t.ojeyinka@yahoo.com 


\begin{abstract}
Most of the extant studies on remittance-growth nexus have been limited to symmetric and linear effects of remittance on economic growth. Unlike previous studies, we examine asymmetric and nonlinear association between remittance and economic growth within the framework of nonlinear autoregressive distributed lag (NARDL) model utilizing Nigeria's data from 1981 to 2018. The study finds the evidence to support that growth responds asymmetrically to remittances only in the long-run. It is established that both positive and negative variations in remittance inflows dampen the productive base of the economy in the long-run while positive and negative changes in remittances are growth-retarding and growthenhancing respectively in the short-run. The study, therefore, concludes that persistent increase in remittance inflows have not been channeled to productive ventures that are capable of stimulating growth in Nigeria. Thus, consistent with the view of pessimistic theorists, continual inflows of remittances to Nigeria could not be termed brain gains to the economy.
\end{abstract}

KEYWORDS: Remittances, Economic growth, Non-linear ARDL, Asymmetric effects, Nigeria JEL CLASSIFICATION: F24, F43, O11 


\section{Introduction}

There are both theoretical and empirical evidence that suggest asymmetric effects of remittances on economic growth. From the theoretical side, remittance flow to the recipient country can help in the provision of housing, meeting children's education and investment in local projects at the household level (Adam and Page, 2005 and Hassan and Shakur, 2017). This is the submission of the optimistic view that remittances play a positive role in the development of the recipient countries. On another note, it has also been proposed that remittance flow can equally have negative consequence of deterioration of balance of trade through excessive import, labour and productivity loss as a result over dependence on remittance by the home country. Another negative effect of migration was put forward by Naidith, Tomini and Lakhdar (2015) that high remittance inflow may improve the economic condition of recipients in the home country and then create disincentive to hard work. This is the view of the pessimistic theorists. In addition, another possible outcome that can result from remittance flow is the effect of migration on the composition of labour force on the home country. The concern has been the loss of skilled man power through migration which is far greater than the remittance itself which is called the brain drain (Lowell and Findlay, 2001). Pang, Lansan and Haines (2002) concluded that migration of each professional in Africa represents a loss of US\$184,000 to the continent. On the other hand, it has been argued in the remittance-growth literature that the labour loss through migration is a temporary issue. The potential benefit of skilled migration from remittances, return migration, technology transfer, skill development and the possible human capital development at home may outweigh the initial short-term of labour loss of the labour-exporting countries. This argument is termed brain gain (Stark and Wang, 2002, Domingues Dos Santos and Postel-Vinay, 2003). The empirical literature on the impact of remittances on growth has however remained inconclusive within specific-country study and across-country studies (Chami et al. (2008), Clemens and Mackenzie 2014)

The motivation for this study on Nigeria is that the country has been the one of the major labour -exporting countries in Africa due to poor working and economic condition. For instance, the number of professional migrants doubled from 465,932 to 1,030,322 people in 1990 to 2013 (International Organization for Migration (IOM), 2014). By 2015, the number of migrants in Nigeria has increased to $1,199,115$ representing $0.66 \%$ of the total population (World Bank, 2015). As a result of high migrant profile for the country, Nigeria has been the highest recipient of remittances in Africa. Record from World Migration Report (2018) showed that remittance 
flow to Nigeria in 2016 was $\$ 19.0$ billion, it increased to $\$ 21.9$ billion in 2018 and increased to $\$ 23.8$ billion by 2019 (See Figure 1). The purpose of this study, therefore, is to examine possible asymmetric effects of remittances on Nigeria's economy. This study tends to know if the remittance flow into the country over the period of study has been negative or positive in the short and long run.

The paper is structured as follows, following the introduction, section 2 presents the literature review; data and methodology are discussed in section 3. Presentation of results and discussion of findings are presented in section 4 and section 5 concludes the study.

\section{Nigeria was the highest recipient of remittances in 2019}

\$ billions

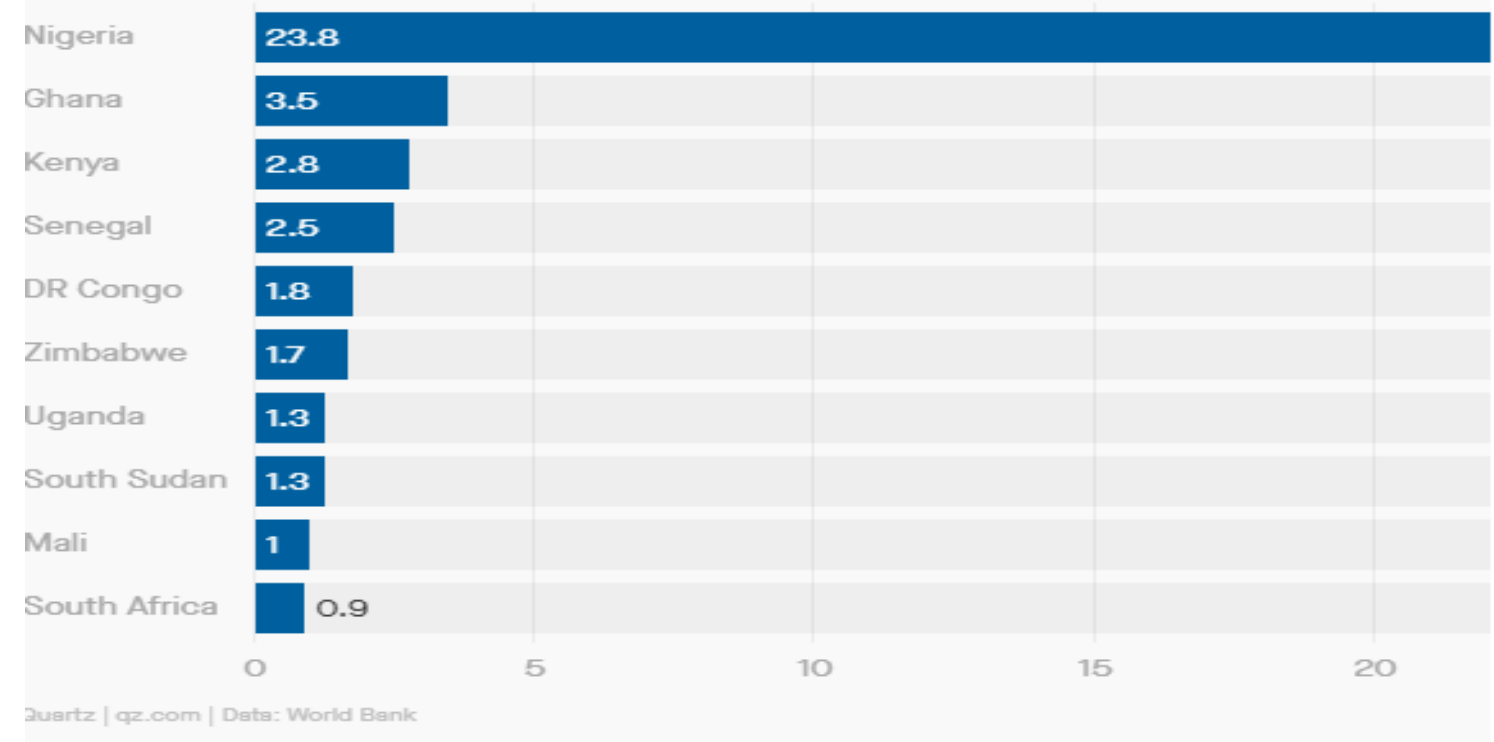

Source: World Bank 2020.

Figure 1. Remittance flows to selected sub-Saharan African countries

\section{Literature Review}

\subsection{Remittance-growth theories}

There are two strands of theory as regards to migrants' remittances and growth. These are the optimistic and the pessimistic views. First, the optimistic theory sees migration as an opportunity to develop the recipient countries with the money remitted to the beneficiaries in terms of increase in income, investment and the overall development of the receiving countries. In the same vein, it is believed that the acquisition of skills, capital and knowledge of the 
migrants would be of immense help to the home country when the migrants finally returns to the country of origin. Migrants are expected to invest large sum of income into their home country so as to have something to fall back on their final return. This is regard to brain gain from the foreign country to the home country. The proponents of the optimistic theory are Lewis (1954), Todaro (1969) and and Beijer (1970). However, the pessimistic theory, on the other hand, views migration as a loss to the home country in terms of physical and human capital due to loss of professionals such as health workers, professionals and academics who have been trained and invested on in the home country. The proponents such as Lipton (1980), Rubenstein (1992) and Russell (1992) among others are of the opinion that remittances from migration have not significantly contribute to the growth process in developing countries. Migration is therefore seen as a brain drain to the home countries.

\subsection{Review of Empirical Literature}

Siddique et al (2010) investigated the causal link between remittances and economic growth in three countries, Bangladesh, India and Sri Lanka, by employing the Granger causality test under a vector autoregressive (VAR) framework. A panel data from 1976 to 2006 was used. It was found that growth in remittances does lead to economic growth in Bangladesh. In India, there seemed to be no causal relationship between growth in remittances and economic growth; but in Sri Lanka, a two-way directional causality was found, which means economic growth influences growth in remittances and vice-versa. Khan and Azam (2011) explored theoretically and empirically the impact of workers' remittances on economic growth of Azerbaijan and Armenia's economies. The finding of the study indicated that workers' remittances are significant and have positive impacts on economic. Javid et al (2012) focused on the importance of remittances inflow and its implication on economic growth and poverty reduction in Pakistan. The techniques of Autoregressive Distributed Lagged (ARDL) approach was used to analyze the impact of remittances inflow on economic growth and poverty in Pakistan for the period 1973 to 2010. Remittances were found to affect economic growth positively and significantly with a strong and statistically significant impact on poverty reduction.

Alkhathlan (2013) also used the ARDL model and Error Correction Model (ECM) techniques to empirically investigate the relationship between economic growth and outflows of workers' remittances in Saudi Arabia from 1970 to 2010. The ARDL technique in the assessment of cointegration showed that an increase in the outflow of workers' remittances had a negative and 
statistically significant short term effect on economic growth in Saudi Arabia. In the long term, the results showed that there is a negative but statistically significant relationship between outflows of workers' remittance and economic growth. Meyer and Shera (2013) studied the impact of remittances on various macroeconomics and developmental aspects of the some economies. A panel data of 21 developing countries during the period 1992 to 2012 was used to observe the impact of remittances on economic growth. The results showed that remittances do have positive impact on the growth of the GDP per capita of Albania and that a 1 percent increase in remittance leads to a 0.14 percent increase in the GDP per capita income.

Goschin (2013) showed that depending on their concrete destination, the remittance flows are used either as additional revenue for household consumption or as investments. Either way, they can impact economic growth from the demand side or from the supply side. The main result of this work is a significant positive impact of remittance inflow on the economic growth in Romania over 1994 to 2011. Feeny et al (2014) investigated the linkage between remittance inflows and per capita income growth, using countries classified as Small Island Developing States (SIDS). The study involved an analysis of data for 136 states developing countries, including 25 SIDS, for the period 1971 to 2010. The results suggest that while there is on average no association between remittances and growth in developing countries, there is a positive association in SIDS. This finding holds for SIDS located in Sub-Sahara Africa and the Pacific but not for those located in Latin America and the Caribbean. Growth in Pacific SIDS was found to be substantially lower in the absence of remittance inflows.

- Sarkar and Datta (2014) made an attempt to analyze the impact of remittance on economic growth in the Bangladesh economy, using time series econometric techniques, specifically, the autoregression distributed lagged (ARDL) framework was adopted for the period of 1975 to 2011. The findings of this study showed that in Bangladesh, there is a possibility of a long-run relationship between remittances and GDP, but there is no predictive causal relationship, neither in the short run nor in the long run.

Blouchoutzi and Nikas (2014) on the other hand used ordinary least square (OLS) method to examine the macro economic effects of remittances in two small transition emigration countries namely: Moldova and Albania. The study covered a period of 1990 to 2010. The findings suggested that remittances contribution to all the three sectors of Moldova's with the same results for Albania. Adarkwa (2015) examined the impact of remittances on economic growth in four selected West African countries; Cameroon, Cape Verde, Nigeria and Senegal for the period of 2000 to 2010. Using a linear regressive model, the result revealed that remittances have positive effects on Senegal and Nigeria's economy while, remittances have negative 
effects on Cape Verde and Cameroon. Studies on direct or indirect link of the remittancefinancial development-growth have given mixed results depending on the sample of the countries and regions chosen. Akkoyunlu (2013) carried out a study on Turkey and investigated the relationship between remittances and financial development from 1963 to 2009. The results showed absence of direct link between remittances and financial development for the country. In another study, Karikari et al. (2016) examined causality between remittances and financial developments in selected countries in Africa, employing a panel data of 50 developing African countries from 1990 to 2011 is used. The findings generally indicated that remittances positively and significantly impact on financial development in the selected countries. Imai et al (2014) explored the effects of remittances on the economic growth of 24 Asia and Pacific countries during 1980 to 2009 using panel data analysis. The result also found remittances to positively affect growth and reduce poverty of the selected countries. Cooray (2012) showed using a panel data for the period of 1970 to 2008 that a significant positive interactive effect of remittances on economic growth is present in South Asia. Akonji and Wakili (2013) examined the impact of remittances on economic growth in Nigeria from 1980 to 2010. The study adopted the use of seemingly unrelated regression (SUR) analysis and error correction model (ECM). The results suggested a significant relationship between remittances and economic growth in Nigeria with well functional financial development.

Koay and Choong (2013) investigated the nexus between remittance and economic growth with the development in financial sector in Malaysia over the period from 1975 to 2009. The results showed remittances and financial development to have significant effects on the economic growth in Malaysia both in the short and long run.

Sibindi (2014) investigated the causal relationship between the remittances, financial development and economic growth in Lesotho for the period 1975 to 2010. The results revealed that remittances Granger cause economic growth without feedback and financial development also Granger causes remittances without feedback.

Sobiech (2015) measured the importance of remittances and financial development for 54 developing countries using a panel data for 1970 to 2010. The study calculated a financial sector development index. The results showed a significant negative effects of remittances on developing countries while positive effects were found for the least advanced countries Furthermore, Iheke (2012) examined the effect of remittances on the Nigerian economic performance. It employed secondary data from 1980 to 2008. Using trend and regression analysis, the study found positive and significant influence on output. Also, Adeagbo and Ayansola (2014) analyzed how remittance impacts on development in Nigeria. The study 
reveals the existence of a positive relationship between remittances and economic development. Olayungbo and Ahmod (2019) found positive effects of remittances and financial development on economic growth of 20 selected African countries, in the short and long run. The study applied pooled mean group and mean group-ARDL and Granger causality test. Finally, the study by Yannick and Roger (2020) investigated the effects of remittances and financial inclusion on income inequality using a panel of 47 countries for the period of 2004 to 2014. The study found remittances to reduce income inequality through financial inclusion.

In summary, the literature review has shown that most study are on the effects of remittances on growth. No known study has examined the asymmetric effects of remittances on Nigeria's economy which this study intends to fill in the literature.

\section{Data and Methodology}

\subsection{Theoretical Framework and Model Specification}

Todaro and Smith (2015) identified domestic and foreign savings as the two principal drivers of economic growth in an economy. This is based on the fact that the required investment to spur economic growth can only be achieved when sufficient saving is mobilised. Given the saving-investment gap in developing countries including Nigeria, remittance could serve as an alternative channels to mobilise resources to achieve the desired growth in the economy. Similarly, in the neoclassical growth model, Solow (1956) emphasises three components of economic growth which are of prime importance namely capital accumulation, population growth and technological progress. To investigate the effect of remittance on economic growth in Nigeria, this study adopts the Solow Neoclassical growth model of Cobb-Douglas production function as presented below:

$Y_{t}=A L_{t}^{\alpha_{1}} K_{t}^{\alpha_{2}}$

Where $\mathrm{Y}$ is aggregate production which represents economic growth, $\mathrm{L}$ is labour to proxy by labour force participation rate, $\mathrm{K}$ is capital accumulation and $\mathrm{A}$ represents technological progress and other factor inputs that affect growth. In the developing countries, technological progress is taken as given and this represents the constant term in the model.

If we log linearize equation (1) we have

$$
y_{t}=a+\alpha_{1} l_{t}+\alpha_{2} k_{t}
$$

Furthermore, the study by Kidozi (2019) argues that remittance promotes growth through technological diffusion in the recipient countries. This is based on the notion that the effect of remittance will amplify the contribution of other factor inputs in stimulating economic growth in the migrants' home country. Hence, incorporating the remittances variable in equation (2) gives

$$
y_{t}=a+\alpha_{1} l_{t}+\alpha_{2} k_{t}+\alpha_{3} r e m_{t}
$$


Following the studies of (Kumar, 2013; Chowdhury, 2016; Kadozi, 2019; Olayungbo, 2019), we introduce other control variables which have been identified to affect economic growth. Following these studies, we re-specify equation (3) as

$$
g r w_{t}=a+\alpha_{1} l b f_{t}+\alpha_{2} g c f_{t}+\alpha_{3} \text { rem }_{t}+\alpha_{4} \text { find }_{t}+\alpha_{5} \inf _{t}+\alpha_{6} \text { open }_{t}+\alpha_{7} \text { exr }_{t}
$$

Where $g r w$ is economic growth proxy with log of real GDP, $l b f$ is labour force participation rate to proxy labour while $g c f$ is gross fixed capital formation to account for the role of capital, rem is remittances received from abroad, find is financial development using domestic credit to private sector, inf represents inflation, opencaptures trade openness and exr is the exchange rate which measures the value of Nigerian currency against the United States dollar. In terms of a-priori expectation, we expect inflation to affect economic growth negatively while labour force participation rate, gross fixed capital formation, financial development and trade openness should have positive affect on economic growth. However, the literature is unclear on the impact of remittance on economic growth. While some studies find that increase in remittance flow enhances economic growth as remittance provides additional saving to augment domestic saving and hence stimulate investment that will spur growth (Imai et al, 2014; Adarkwa, 2015; Edward, 2019), other studies argue that remittance inflows retard economic growth (Sobiech, 2015; Olaniyan, 2019; Anetor, 2019). However, unlike previous studies, our study decomposed the remittances variable into positive and negative components to test for the asymmetric relationship remittance flow and economic growth in Nigeria which is the core objective of the study.

\subsection{Methodology and Technique of Estimation.}

One major aim of this study is to explore the short run and long run asymmetric effects of remittance on economic growth in Nigeria. To achieve the study objective, we first estimate the standard Autoregressive Distributed Lag Model proposed by Pesaran, Shin and Smith (2001) and thereafter employ the non-linear ARDL proposed by Shin, Yu, and GreenwoodNimmo (2014) to uncover the possibility of asymmetric relation between remittance inflow and economic growth in Nigeria. The ARDL technique is employed due to its potency to handle variables of mixed order of integration and the ability to estimate both short run and long run relations. In line with the Pesaran et al (2001), the ARDL version of equation (4) is presented in equation 5 as

$$
\begin{aligned}
& \Delta g r w_{t}=a+\sum_{j=1}^{n 1} \delta_{1 j} \Delta g r w_{t-j}+\sum_{j=0}^{n 2} \delta_{2 j} \Delta l b f_{t-j}+\sum_{j=0}^{n 3} \delta_{3 j} \Delta g c f_{t-j}+\sum_{j=0}^{n 4} \delta_{4 j} \Delta r e m_{t-j}+\sum_{j=0}^{n 5} \delta_{5 j} \Delta \text { find }_{t-j} \\
& +\sum_{j=0}^{n 6} \delta_{6 j} \Delta \inf _{t-j}+\sum_{j=0}^{n 7} \delta_{7 j} \Delta \text { open }_{t-j}+\sum_{j=0}^{n 8} \delta_{8 j} \Delta e x r_{t-j}+\theta_{1} g r w_{t-1}+\theta_{2} l b f_{t-1}+\theta_{3} g c f_{t-1} \\
& +\theta_{4} \text { rem }_{t-1}+\theta_{5} \text { find }_{t-1}+\theta_{6} \inf _{t-1}+\theta_{7} \text { open }_{t-1}+\theta_{8} \text { exr }_{t-1}+\varepsilon_{t}
\end{aligned}
$$

From equation (5), $\Delta$ is the first difference operator and the coefficients $\left(\delta^{\prime} s\right)$ represent the short run effects while the long run coefficients are derived by normalizing estimates $\theta_{2}-\theta_{8}$ on $\theta_{1}$. Similarly, $n 1-n 8$ are lags length and $\varepsilon$ is serially uncorrelated error term. The first step in performing the ARDL technique is to examine the unit root property of the variables in the 
model to ensure that none of the series is I (2) or higher order. After confirming the unit root property, the next step is to conduct the cointegration test using the Bound Test proposed by Pasaran et al (2001). This is done by testing the null hypothesis of no cointegration using the $\mathrm{F}$ test for joint significance of the lagged level variables in equation (5)

( $\left.H_{0}: \theta_{1}=\theta_{2}=\theta_{3}=\theta_{4}=\theta_{5}=\theta_{6}=\theta_{7}=\theta_{8}=0\right)$. Pasaran et al, (2001) proposed two bounds the lower bound $\left(\mathrm{I}_{0}\right)$ and upper bound $\left(\mathrm{I}_{1}\right)$ to check against the value of the computed F-statistic which are. The null hypothesis of no cointegration is rejected if the value of the computed Ftest is greater that the upper bound critical value. However, if the value of F-statistic falls below the upper bound critical value, the null hypothesis of no cointegration cannot be rejected while the decision is inconclusive if the value of F-test falls between the two bounds.

One major drawback of equation (5) is that it assumes that both increase and decrease in remittance have the same effect on economic growth. However, as argued in the introduction, it is possible for increase and decrease in remittance flow to have differential (asymmetric) effect on economic growth. To capture the asymmetric relations in the model, Shin et al (2014) extended the traditional ARDL by decomposing the target variable (remittance) into positive and negative components as presented below:

$\operatorname{rem}_{t}=\operatorname{rem}_{t}^{+}+\operatorname{rem}_{t}^{-}$

Where $\operatorname{rem}_{t}^{+}=\sum_{i=1}^{t} \Delta \operatorname{rem}_{i}^{+}=\sum_{i=1}^{t} \max \left(\Delta r e m_{i}, 0\right)$ and $\mathrm{rem}_{t}^{-}=\sum_{i=1}^{t} \Delta \operatorname{rem}_{i}^{-}=\sum_{i=1}^{t} \min \left(\Delta r e m_{i}, 0\right)$

In equation (6), $\mathrm{rem}_{t}^{+}$is partial sum of positive changes in remittance and $\mathrm{rem}_{t}^{-}$captures the partial sum of negative changes in remittance. The decomposition of remittance is based on the intuition that when there is an increase in remittance inflows, there is a brain gain to the countries as this is expected to generate productive investment that we stimulate economic activity in the recipient country. On the other hand, the negative components (decrease) of remittance might be conceived as brain drain for the migrant's home countries in the form of labour loss which is expected to slow down the pace economic growth.

Therefore, if the remittance variable in equation (5) is replaced with positive and negative components in equation (6), we have the asymmetric ARDL model as presented below:

$$
\begin{aligned}
& \Delta g r w_{t}=\eta+\sum_{j=1}^{q 1} \lambda_{1 j} \Delta g r w_{t-j}+\sum_{j=0}^{p 2} \lambda_{2 j} \Delta l b f_{t-j}+\sum_{j=0}^{p 3} \lambda_{3 j} \Delta g c f_{t-j}+\sum_{j=0}^{p 4} \lambda_{4 j} \Delta r e m_{t-j}^{+}+\sum_{j=0}^{p 5} \lambda_{5 j} \Delta r e m_{t-j}^{-} \\
& +\sum_{j=0}^{p 6} \lambda_{6 j} \Delta \text { find }_{t-j}+\sum_{j=0}^{p 7} \lambda_{7 j} \Delta \inf _{t-j}+\sum_{j=0}^{p 8} \lambda_{8 j} \Delta \text { open }_{t-j}+\sum_{j=0}^{p 9} \lambda_{9 j} \Delta \operatorname{exr}_{t-j}+\varphi_{1} \text { grw }_{t-1}+\varphi_{2} \text { lbf }_{t-1}+ \\
& \varphi_{3} g c f_{t-1}+\varphi_{4} \text { rem }_{t-1}^{+}+\varphi_{5} \text { rem }_{t-1}^{-}+\varphi_{6} \text { find }_{t-1}+\varphi_{7} \inf _{t-1}+\varphi_{8} \text { open }_{t-1}+\varphi_{9} \text { exr }_{t-1}+\mu_{t}
\end{aligned}
$$

Equation (7) captures both the short run and long run asymmetric effects of remittance on economic growth with the estimates $\lambda s$ and $\varphi s$ representing the short run and long run coefficients respectively. To test for the asymmetric effect of remittance on economic growth, we follow previous studies by computing the Wald test on the magnitude of the positive and 
negative components of remittance (Kisswani and Kisswani, 2019; Bahmani-Oskooee and Nouira, 2019). The major criteria is to reject the null hypothesis of symmetric relation between remittance and economic growth if the coefficient of positive components is significantly different from that of the negative component. That is, if the Wald test rejects the null hypothesis that $\sum \lambda_{4 j}=\sum \lambda_{5 j}$, there is evidence of short run asymmetric effects of remittance on economic growth. On the other hand, if the Wald test reject the null of $-\frac{\varphi_{4}}{\varphi_{1}}=-\frac{\varphi_{5}}{\varphi_{1}}$, long run asymmetric effect of remittance on economic growth will be established.

After testing for the presence of asymmetry between remittance and economic growth, we proceed by computing the dynamic multiplier effects of positive and negative components of remittance on economic growth. Following the studies of Shin et al (2014) and Alsamara, Mrabet, Donbrecht and Barkat (2016), we generate the dynamic multipliers from equation (7) $m_{h}^{+}$and $m_{h}^{-}$associated with changes in the positive and negative components of remittance respectively as follow:

$m_{h}^{+}=\sum_{i=0}^{h} \frac{\partial g r w_{t+i}}{\partial r e m_{t}^{+}}, \quad m_{h}^{-}=\sum_{i=0}^{h} \frac{\partial g r w_{t+i}}{\partial r e m_{t}^{-}}, \quad$ Where $h=0,1,2$.

It is important to state that as $h \rightarrow \infty, m_{h}^{+} \rightarrow \varphi_{4}$ and $m_{h}^{-} \rightarrow \varphi_{5}$ where $\varphi_{4}$ and $\varphi_{5}$ are the long run parameters associated with positive and negative components of remittance inflows respectively.

\subsection{Sources of Data and Variable Description}

The data for this study are obtained from World Development Indicator of World Bank, 2019 edition. We use real GDP to proxy economic growth while the gross fixed capital formation as a ratio of GDP is adopted as a measure of investment. We use labour force participation rate to proxy labour. Labour force participation rate is the ratio of active population to total population (people within the age of 15-64 years). In line with studies such as (Jouini, 2015; Chowdhury, 2016), we employ domestic credit to private sector as a share of GDP to proxy the level of financial development in Nigeria. For remittance variable, we use personal remittance received as a proportion of GDP. According to the World Bank definition, personal remittance is the sum of personal transfers and compensation of employees by Nigerian abroad. Trade openness in the study is computed as the ratio of total trade to GDP. To account for the level of uncertainty in the economy, we include inflation rate measured by consumer price index in the model. Lastly, the study incorporates exchange rate and population as other determinants of economic growth in Nigeria. Consistent with extant studies (Olaniyi, 2019; Meo et al., 2018; Shahbaz et al, 2017), it should be emphasized that natural logarithms of all the variables are taken so as to forestall problems of outliers and heteroskedascity.

\section{Presentation of results and discussions of findings.}

\subsection{Descriptive statistics}

Before proceeding on the empirical examination of linear and nonlinear effects of remittances on economic growth in Nigeria, descriptive statistics of the variables are examined so as to reveal the nature and characteristics of the variables and how they behave over the 
study period. Table 1 provides detailed descriptive statistics of the variables. The link between standard deviation and mean values explain the extent to which mean represents the actual dataset. Variables such as economic growth (lgrw), gross fixed capital formation as a ratio of GDP $(l g c f)$ and personal remittance received as a proportion of GDP (lrem) appear to have significantly spread out from their respective average values. It implies they are unstable and somewhat volatile. Other variables in the study are relatively stable and less volatile as their data appear to have somewhat clustered around their respective mean values. The coefficients of Kurtosis indicate that the variables such as labour force participation (llbf), gross fixed capital formation as a ratio of GDP $(\operatorname{lgc} f)$, and trade openness (lopen) are leptokurtic (peak), while other variables such as real GDP, a proxy for economic growth $(\lg r w)$, remittances (lrem), financial development, a domestic credit to private sector as a ratio of GDP (lfind), inflation (linf), and exchange rate (lexr) are platykurtic. None of the variables is mesokurtic. Thus, it is obvious that the variables do not exhibit elements of exact normal distribution. The variables are not symmetric in their data distribution. They portray elements of asymmetric distribution in their data spreading.

Table 1: Descriptive Statistics

\begin{tabular}{lcccccccc}
\hline Statistics & lgrw & llbf & lgcf & lrem & lfind & linf & lopen & lexr \\
\hline Mean & 26.090 & 4.084 & 24.735 & 20.329 & 2.150 & 2.686 & 3.372 & 3.418 \\
Median & 25.883 & 4.095 & 24.712 & 20.831 & 2.097 & 2.543 & 3.525 & 4.574 \\
Maximum & 26.896 & 4.114 & 25.378 & 23.914 & 2.977 & 4.288 & 3.976 & 5.724 \\
Minimum & 25.404 & 3.986 & 24.353 & 14.701 & 1.601 & 1.684 & 2.212 & -0.482 \\
Standard Deviation & 0.516 & 0.041 & 0.214 & 3.188 & 0.355 & 0.701 & 0.500 & 1.976 \\
Skewness & 0.320 & -1.625 & 0.664 & -0.352 & 0.556 & 0.836 & -1.071 & -0.763 \\
Kurtosis & 1.585 & 4.060 & 3.817 & 1.696 & 2.525 & 2.781 & 3.118 & 2.270 \\
Jarque-Bera & 3.821 & 18.508 & 3.850 & 3.477 & 2.317 & 4.498 & 7.291 & 4.533 \\
Probability & 0.148 & 0.000 & 0.146 & 0.176 & 0.314 & 0.105 & 0.026 & 0.104 \\
\hline
\end{tabular}

The coefficients of skewness also support that the data are not symmetrically distributed. It rather shows properties of clear asymmetries in data distribution. The data do not follow a typical bell shape. They are either skewed positively or negatively to the left or right. The distributions are not symmetrical. Similarly, the Jarque-Bera statistics reveal that most of the series, except llbf and lopen, are normally distributed. This might have justified the importance of using nonlinear and asymmetric method of analysis (Olaniyi \& Olayeni, 2020; Shahbaz et al., 2017) of remittance-growth nexus in Nigeria. The features of the variables suggest symmetric approach may give suboptimal results.

\subsection{Unit Root Tests}

In order to ensure right application of estimation technique, stationarity properties of the variables are examined in this subsection. Though ARDL and NARDL do not require pretesting of unit root test. Meanwhile, it is necessary because ARDL and NARDL estimation techniques break down whenever any of the variables is integrated of order two [I(2)]. Thus, an array of unit root tests are carried out. In an attempt to ensure the robustness of results of unit root tests, three dimensions of unit root tests are considered. Linear unit root test, Unit root test with structural break and nonlinear unit root tests. The two most popular linear unit root tests such as Augmented Dickey Fuller (ADF) and Phillips-Perron (PP) are examined. The results of $\mathrm{ADF}$ and $\mathrm{PP}$ in Table 2 indicate that majority of the variables are integrated of order one $[I(1)]$ while only inflation rate $(\operatorname{linf})$ and gross fixed capital formation $(\operatorname{lgcf})$ are 
stationary at level. Other variables such as lgrw, lrem, lfind, lopen and lexr attain stationarity at first differences $[I(1)]$.

Meanwhile, it has been suggested in the extant literature that ADF and PP unit root tests have low power when there are evidence of structural break in the series (Olaniyi \& Oladeji, 2020). Following this assertion, Zivot \& Andrews (1992) unit root test which accommodates the presence of structural break is adopted. The synopsis of results of Zivot-Andrew unit root test which takes cognizance of a single structural break are presented in Table 3 . The results of Zivot-Andrew unit root tests indicate that variables such as $l l b f, \lg c f$, lfind and $\operatorname{lin} f$ are stationary at level without passing through the process of first-differencing. The remaining variables all become stationary at first differences. It could be deduced that both linear and structural break unit root tests support the mixed orders of integration of the variables. Furthermore, it has been suggested in the recent literature that traditional unit root test as presented above exhibit low power when nonlinearity and asymmetric structures in the data are ignored (Shahbaz, Khraief \& Czudaj, 2020; Otero \& Smith, 2017). Also, consistent with the main objective of this study which is to examine the nonlinear and asymmetric effects of remittances on economic growth, it will not be intellectually sound to rely solely on linear unit root tests when there is evidence of nonlinearity and asymmetries (Dong, Gozgor Lu \& Yan, 2020). It has been affirmed that Kapetanios \& Shin (2008), KS, accounts for nonlinearity and asymmetries (Dong et al., 2020) which is consistent with the objective of this study. Hence, following the propositions of Kapetanios, Shin \& Snell (2003) and Kapetanios \& Shin (2008) which suggest KSS and KS tests respectively. These tests are within the framework of globally stationary exponential smooth transition autoregressive (ESTAR) process and Monte Carlo simulation that are based on a nonlinear model. The results of KSS and KS tests reveal that all variables are integrated of order one. It is important to note that the optimal lag length of the results of KSS and KS tests reported in Table 4 are premised on Schwarz information criterion (SIC). Other lag length criteria are important but for sake of consistence, SIC is chosen.

Table 2: Linear Unit Root Tests

\begin{tabular}{|c|c|c|c|c|c|c|c|c|}
\hline \multirow[t]{3}{*}{ Variables } & \multicolumn{4}{|c|}{ Level } & \multicolumn{4}{|c|}{ First Difference } \\
\hline & \multicolumn{2}{|c|}{ Intercept } & \multicolumn{2}{|c|}{ Intercept \& Trend } & \multicolumn{2}{|c|}{ Intercept } & \multicolumn{2}{|c|}{ Intercept \& Trend } \\
\hline & $\mathrm{ADF}$ & PP & $\mathrm{ADF}$ & PP & $\mathrm{ADF}$ & PP & $\mathrm{ADF}$ & $\mathrm{PP}$ \\
\hline lgrw & -0.195 & 0.611 & -1.553 & -2.746 & $-5.236 * * *$ & $-5.204 * * *$ & $-4.961 * * *$ & $-4.955^{* * *}$ \\
\hline llbf & -0.324 & 0.762 & -1.777 & -0.912 & $-3.352^{* *}$ & $-3.477 * *$ & $-4.204 * *$ & $-3.466^{*}$ \\
\hline $\operatorname{lgcf}$ & -2.361 & -3.505 & $-6.640 * * *$ & $-4.721 * * *$ & $-4.874 * * *$ & $-5.443 * * *$ & $-5.140 * * *$ & $-5.738 * * *$ \\
\hline lrem & -0.719 & -0.719 & -2.090 & -2.126 & $-6.242 * * *$ & $-6.242 * * *$ & $-6.151^{* * *}$ & $-6.151^{* * *}$ \\
\hline lfind & -1.728 & -1.636 & $-4.00 * *$ & -2.296 & $-5.431 * * *$ & $-7.890 * * *$ & $-5.318 * * *$ & $-7.754 * * *$ \\
\hline $\operatorname{linf}$ & $-3.353 * *$ & $-3.234 * *$ & $-4.393 * * *$ & -3.173 & $-6.776^{* * *}$ & $-9.319 * * *$ & $-6.673 * * *$ & $-9.774 * * *$ \\
\hline lopen & -1.870 & -1.870 & -1.985 & -1.904 & $-7.252 * * *$ & $-7.264 * * *$ & $-7.259 * * *$ & $-7.510 * * *$ \\
\hline lexr & -1.989 & -2.122 & -1.283 & -1.290 & $-5.170 * * *$ & $-5.170^{* * *}$ & $-5.526^{* * *}$ & $-5.713 * * *$ \\
\hline
\end{tabular}

Note: $* * * * *$ and $*$ denote are $1 \%, 5 \%$ and $10 \%$ levels of significance.

ADF stands for Augmented Dickey Fuller and PP represents Phillips-Perron 
Table 3: Unit Root Test with structual break

\begin{tabular}{|c|c|c|c|c|c|c|c|c|}
\hline \multirow[t]{2}{*}{ Variables } & \multicolumn{4}{|c|}{ Level } & \multicolumn{4}{|c|}{ First Difference } \\
\hline & Intercept & Break & Intercept \& Trend & Year of break & Intercept & Break & Intercept \& Trend & Break \\
\hline & \multicolumn{3}{|c|}{ Zivot-Andrews } & & \multicolumn{3}{|c|}{ Zivot-Andrews } & \\
\hline lgrw & -2.948 & 2001 & -2.885 & 1992 & $-4.995 * *$ & 2000 & $-5.365^{* *}$ & 2001 \\
\hline llbf & $-12.980 * * *$ & 2012 & $-5.640 * * *$ & 2012 & $-6.617 * * *$ & 2012 & $-18.852 * * *$ & 2012 \\
\hline $\operatorname{lgcf}$ & -4.660 & 1996 & $-6.159 * * *$ & 2001 & $-4.789 *$ & 2001 & -4.364 & 2011 \\
\hline lrem & -3.925 & 1993 & -4.134 & 2005 & $-7.863^{* * *}$ & 1989 & $-7.904 * * *$ & 1994 \\
\hline lfind & $-6.114 * * *$ & 2007 & $-7.488 * * *$ & 2007 & $-5.623 * * *$ & 1993 & $-4.971 *$ & 2006 \\
\hline $\operatorname{linf}$ & $-5.311 * *$ & 1997 & $-6.411 * * *$ & 1997 & $-5.530 * * *$ & 1996 & $-5.493 * *$ & 1996 \\
\hline lopen & -3.855 & 1989 & -4.512 & 1989 & $-5.623 * * *$ & 1993 & $-4.971 *$ & 2006 \\
\hline lexr & -2.445 & 1990 & -3.618 & 1999 & $-5.790 * * *$ & 2001 & $-5.024 *$ & 2004 \\
\hline
\end{tabular}

Note: $* * *, * *$ and $*$ denote $1 \%, 5 \%$ and $10 \%$ levels of significance.

Zivot and Andrews (1992) Unit Root Test

Table 4: Nonlinear Unit Root Tests(Stationary nonlinear ESTAR models)

\begin{tabular}{lccccc}
\hline Variables & \multicolumn{2}{c}{ Level } & & \multicolumn{2}{c}{ First Difference } \\
\cline { 2 - 3 } \cline { 5 - 6 } lgrw & KS & KSS & & KS & KSS \\
\cline { 2 - 3 } \cline { 5 - 6 } llbf & -0.856 & -0.415 & & $-2.466^{*}$ & $-2.849^{* *}$ \\
lgcf & -0.356 & -0.359 & & $-2.702^{* *}$ & $-2.709^{* *}$ \\
lrem & -1.968 & -2.188 & & $-2.923 * *$ & $-3.920^{* * *}$ \\
lfind & -0.514 & -1.299 & & $-3.109^{* *}$ & $-3.108^{* *}$ \\
linf & -1.475 & -1.764 & & $-2.634^{* *}$ & $-2.631^{*}$ \\
lopen & -1.779 & -1.569 & & $-3.328^{* * *}$ & $-3.669^{* * *}$ \\
lexr & -2.013 & -2.283 & & $-3.576^{* * *}$ & $-4.314^{* * *}$ \\
\hline & 0.888 & 0.621 & & $-4.340^{* * *}$ & $-4.344^{* * *}$ \\
\hline
\end{tabular}

KSS denotes Kapetanios, Shin \& Snell (2003) test

KS denotes Kapetanios \& Shin (2008) test

$* * *, * *$ and $*$ represent $1 \%, 5 \%$ and $10 \%$ levels of significance

\subsection{ARDL cointegration bounds test}

Following the results of robust unit tests discussed earlier, it is evident there is the need to explore the behaviour of the variables in the long-run as the results of unit root tests reveal the possibility of divergent behaviour of the variables in the short-run dynamics. The detailed analyses of ARDL bounds testing for linear and nonlinear models are presented in Table 5. The results of both linear and nonlinear ARDL bound tests reveal that there is a strong evidence of cointegration among the variables. This is confirmed as their respective calculated F-statistic is greater than the upper and lower bounds critical values at 1 percent level of significance. Thus, the null hypothesis of no long-run relationship among the variables is rejected. In a plain language of economics, this suggests that if the variables drift apart and behave differently as a result of factors that causes disequilibrium and divergences in the short-run; the existence of cointegration implies evidence of convergence is guaranteed after a series of distortions and shocks along long-run dynamics (Olaniyi \& Adedokun, 2020). It could also be affirmed that long-run estimates are more predictable as indicated by the results of unit root tests and cointegration. Having confirmed evidence of long-run relationship among the variable in both linear and nonlinear models, a cursory look is taken at the asymmetric structures in the trends of data on remittances. The graphical illustrations of the positive and negative components of 
remittance are presented in Figures 1 and 2. The Figures 1 and 2 confirm the presence of asymmetric structures in the trends and data distribution of the variable over the study period. This process separates the brain gains from brain drains as a result of Nigeria's citizens migrating to other countries which leads to inflows of remittances. The differential impacts of brain gains and brain drains on economic growth in Nigeria are explored in the subsequent section.

Table 5: Linear and Nonlinear ARDL Bounds Tests

\begin{tabular}{|c|c|c|c|c|c|}
\hline \multicolumn{3}{|c|}{ Linear ARDL Bounds Tests } & \multicolumn{3}{|c|}{ Nonlinear ARDL Bound Test } \\
\hline Test Statistic & Value & $\mathrm{k}$ & Test Statistic & Value & $\mathrm{k}$ \\
\hline F-statistic & 9.491 & 7 & F-statistic & 7.872 & 8 \\
\hline Significance & Lower Bound $1(0)$ & Upper Bound 1(1) & Significance & Lower Bound 1(0) & Upper Bound 1(1) \\
\hline $10 \%$ & 2.03 & 3.13 & $10 \%$ & 1.95 & 3.06 \\
\hline $5 \%$ & 2.32 & 3.5 & $5 \%$ & 2.22 & 3.39 \\
\hline $1 \%$ & 2.96 & 4.26 & $1 \%$ & 2.79 & 4.1 \\
\hline
\end{tabular}

Note: $\mathrm{k}$ is the number of exogenous variables in the model

LREM POS

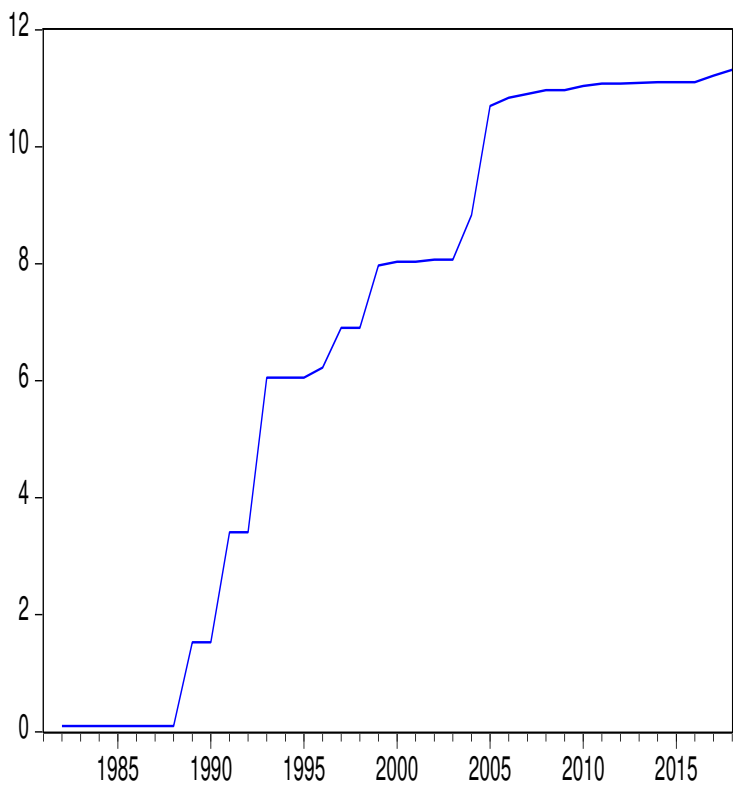

Figure 1: Positive component of Remittances
LREM NEEG

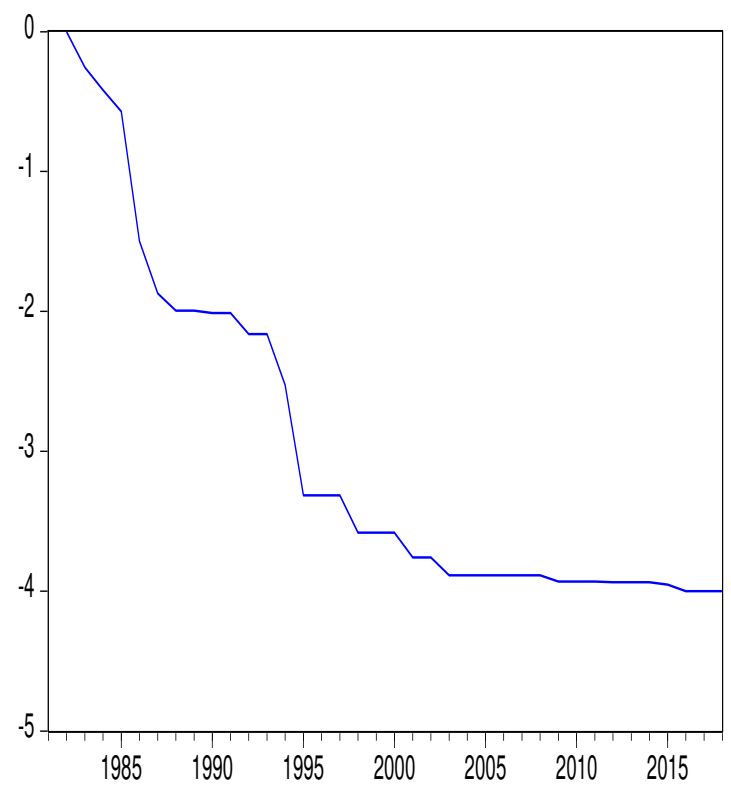

Figure 2: Negative component of Remittances

\subsection{Asymmetries in remittance-growth nexus in Nigeria}

\subsubsection{Testing for asymmetric effects of remittance on economic growth in Nigeria}

Following the popular two dimensions in the extant literature, asymmetric effects are examined in line with short and long-run dynamics. The results of both short and long-run asymmetries in the remittance-growth nexus are presented in Table 6 . The results reveal that there is no evidence of asymmetry in the short-run. However, it suggests there is a strong asymmetry in the relationship between remittances and economic growth in the long-run. Null hypothesis of no asymmetry could not be rejected in the short-run but it is confirmed rejected in the long-run. It is obvious that positive and negative components' shocks of remittances have the symmetric effects on economic growth in Nigeria in the short-run. This implies that the effects of remittances on economic growth are symmetric in the short-run. The implication is that brain gains and brain drains have symmetric effects on economic growth in Nigeria in the 
short-run while growth responds asymmetrically to change in remittances in the long-run. This suggests the importance of asymmetry and it hints that extant studies which ignore the possibility of asymmetric structures in the remittance-growth nexus might have overestimated

Table 6: Tests for short and long-run asymmetries

\begin{tabular}{lc}
\hline Wald Test & $X^{2}$ Statistics \\
\hline$W_{S R}$ & 3.464 \\
$W_{L R}$ & $19.991 * * *$ \\
\hline
\end{tabular}

**** denotes 1 percent level of significance

$W_{S R}$ and $W_{L R}$ stand for short and long-run symmetries respectively

their models. Thus, this present study is justified by examining asymmetric and nonlinear effects of remittances on economic growth. The dynamic multiplier graph is equally sketched to confirm and authenticate the results of asymmetric structures in the effects of remittances on economic growth. The graph also shows that there is no evidence of asymmetry in the shortrun while it reveals a clear evidence of asymmetric structure in long-run. The red thick dotted lines break out in the short-run but falls in-between positive and negative components' multiplier lines in the long-run. The long-run asymmetry established in the study is more tenable and reliable due to the fact that the variables are subject to distortion and divergence in their behaviour along short-run dynamics. Distortions and divergence are confirmed by the various unit root tests (linear and nonlinear) adopted while element of predictability and stability is supported by cointegration test and coefficients of error terms in the linear and nonlinear estimates. This further re-affirms that relying on symmetric approach in examining the relationship between remittances and economic growth tend to produce unrealistic and spurious estimates.

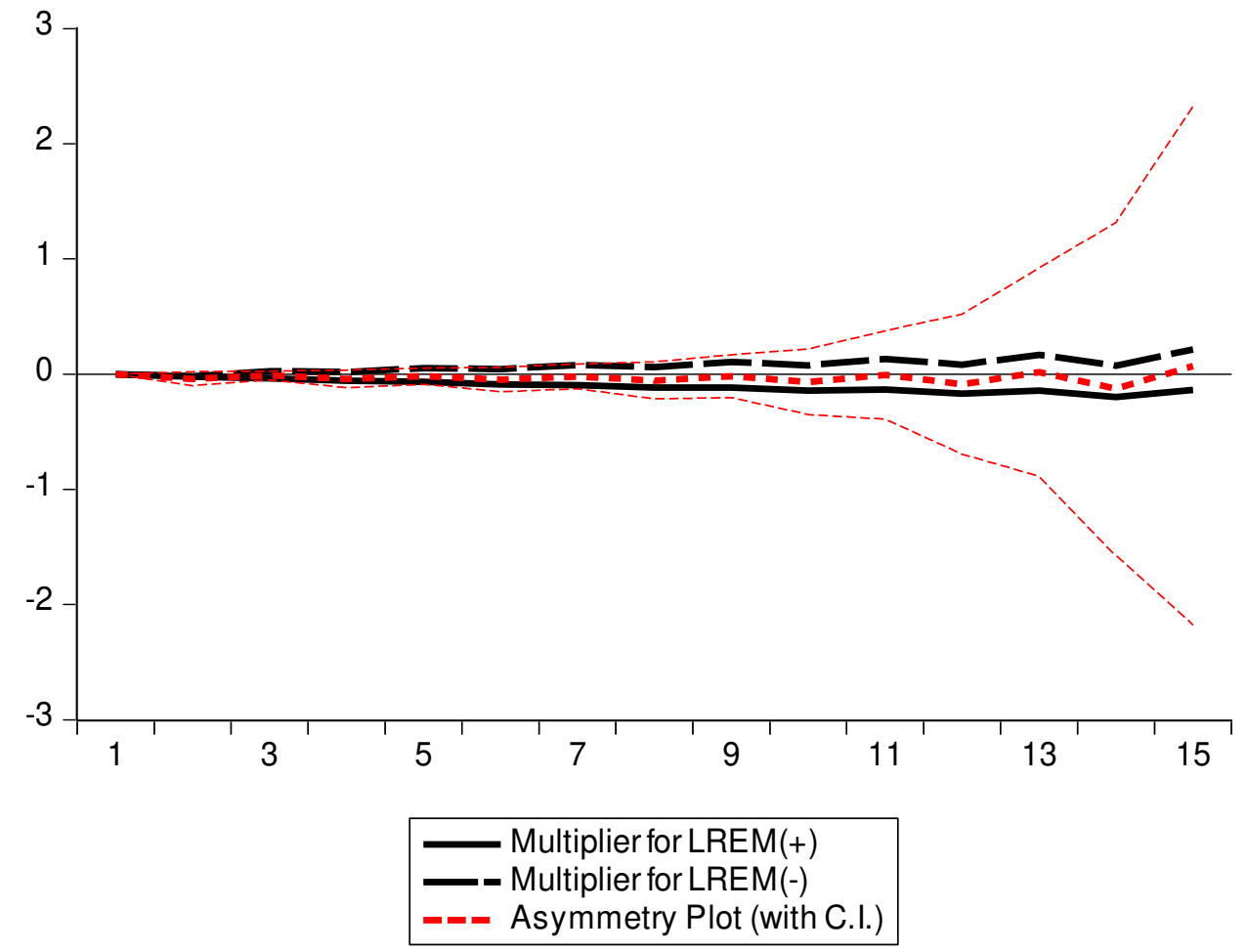

Figure 1: The Graph of Nonlinear ARDL Dynamic Multiplier 


\subsubsection{Linear and nonlinear short and long-run dynamics}

Linear and nonlinear error-correction versions of ARDL estimates are presented and interpreted in this section. This approach helps to separate the short-run dynamics from the long-run dynamics in the remittance-growth nexus (Kratou \& Gazdar, 2015). The results of linear model are presented in Table 7 while the coefficients of short and long-run nonlinear models are provided in Table 8 . The coefficients of error-correction terms (ECT) are negative and statistically significant in both the linear and nonlinear results (see Tables 7 and 8). This confirms the existence of long-run relationship among the variables (Olaniyi \& Adedokun, 2020; Ntembe et al., 2018; Banerjee et al., 1998). These results are consistent with the outcomes of ARDL bound tests for linear and nonlinear models as earlier presented in Table 5. These coefficients measure the extent to which equilibrium is restored per period of time after a series of shocks or divergences from the path of long-run dynamics.

Furthermore, the short-run coefficients (lag 1 and 2) of linear model reveal that remittance (LREM) is an insignificant driver of economic growth in Nigeria (see Table 7). The results, however, change significantly, after accounting for asymmetric structures in the remittance by separating positive shocks' component (brain gains, $L R E M^{+}$) from negative shocks' component (brain drains, $L R E M^{-}$). The short-run coefficients of positive and negative shocks' components in nonlinear estimator are statistically significant at 1 percent level of significance. Meanwhile, the signs of the two coefficients differ. The coefficients of positive shock's component is negative while that of negative shock's component is positive. In the language of economics, this implies that the impact of increase in remittance, brain gains, in the short-run is not beneficial to Nigeria's economy. This rather constitutes a drag to the growth-enhancing activities of the country. The implication is that the opportunity of reaping the benefits of Nigerians migrating to other countries for greener pastures in terms of brain gains is negative in the short-run. This suggests that increase inflows of remittance to Nigeria in the short-run create disincentive to hard work. It may equally indicate that larger proportion of subsisting remittances into the country are channelled to growth-inhibiting ventures rather than growth-promoting investment. This research outcome is in tandem with the findings of some extant studies (Anetor, 2019; Olaniyan, 2019; Sobiech, 2015) which found the adverse effects of increased remittances on economic growth. It equally re-affirms the finding of Kratou \& Gazdar (2015) which established negative impact of increase in inflows of remittance in the short-run. This finding corroborates the assertion of Cazachevici, Havranek \& Horvath, (2020) that more remittances in Africa are not growth-enhancing. Thus, it could be interpreted that more remittance inflows to Nigeria do not constitute brain gains to the economy in the shortrun. The bulk of remittances appear to have been channelled to unproductive activities which leak out the growth prospects of the country

Also, the long-run estimates of the linear and nonlinear models give similar results. The linear long-run estimate identifies remittances as a significant factor and driver of economic growth in Nigeria but its impact is negative. This suggests that inflows of remittances does not have the prospect of enhancing and building up the productive capacities in the long-run. Furthermore, the effect remains negative after the asymmetries and nonlinearities are well accounted for in the nonlinear model. The results reveal the long-run estimates of positive and negative components of remittances are significantly negative. This implies that both increase and decrease in remittances tend to have strong negative effects on economic growth prospect of Nigeria in the long-run. These research outcomes indicate that migration of Nigerians to other countries for greener pastures may not lead to brain gains to the country in the long-run. 
Table 7: Short and Long-run Estimates of linear ARDL $(2,2,1,2,2,2,2,2)$

\begin{tabular}{|c|c|c|c|c|}
\hline \multicolumn{5}{|c|}{ Depdendent Variable: LGRW (Real GDP) } \\
\hline Variable & Coefficient & Std. Error & t-Statistic & Prob. \\
\hline \multicolumn{5}{|c|}{ Short-run coefficients } \\
\hline$\Delta(\operatorname{LGRW}(-1))$ & -0.333 & 0.239 & -1.389 & 0.188 \\
\hline$\Delta(\mathrm{LLBF})$ & $-1.857 * * *$ & 0.642 & -2.894 & 0.013 \\
\hline$\Delta(\operatorname{LLBF}(-1))$ & $-1.264 * *$ & 0.497 & -2.542 & 0.025 \\
\hline$\Delta(\mathrm{LGCF})$ & 0.010 & 0.047 & 0.205 & 0.840 \\
\hline$\Delta(\mathrm{LREM})$ & -0.004 & 0.009 & -0.441 & 0.667 \\
\hline$\Delta(\operatorname{LREM}(-1))$ & 0.007 & 0.007 & 1.034 & 0.320 \\
\hline$\Delta(\mathrm{LFIND})$ & $0.061 *$ & 0.031 & 1.970 & 0.071 \\
\hline$\Delta(\operatorname{LFIND}(-1))$ & -0.034 & 0.026 & -1.318 & 0.210 \\
\hline$\Delta(\mathrm{LINF})$ & $-0.038 * * *$ & 0.011 & -3.530 & 0.004 \\
\hline$\Delta(\operatorname{LINF}(-1))$ & $0.026 * *$ & 0.010 & 2.436 & 0.030 \\
\hline$\Delta(\mathrm{LOPEN})$ & $0.047 * * *$ & 0.016 & 2.920 & 0.012 \\
\hline$\Delta($ LOPEN(-1)) & $0.043^{*}$ & 0.023 & 1.820 & 0.092 \\
\hline$\Delta(\mathrm{LEXR})$ & -0.028 & 0.019 & -1.501 & 0.157 \\
\hline$\Delta(\operatorname{LEXR}(-1))$ & $-0.107 * * *$ & 0.018 & -5.828 & 0.000 \\
\hline $\mathrm{ECT}(-1)$ & $-0.169 * * *$ & 0.052 & -3.259 & 0.006 \\
\hline \multicolumn{5}{|c|}{ Long-run coefficients } \\
\hline LLBF & $5.222 *$ & 2.794 & 1.869 & 0.084 \\
\hline LGCF & 0.471 & 0.318 & 1.480 & 0.163 \\
\hline LREM & $-0.190 * *$ & 0.074 & -2.556 & 0.024 \\
\hline LFIND & $0.813 * * *$ & 0.172 & 4.726 & 0.000 \\
\hline LINF & $-0.344 * *$ & 0.147 & -2.346 & 0.036 \\
\hline LOPEN & $-0.533 * * *$ & 0.169 & -3.158 & 0.008 \\
\hline LEXR & $0.537 * * *$ & 0.163 & 3.300 & 0.006 \\
\hline $\mathrm{C}$ & -3.542 & 13.214 & -0.268 & 0.793 \\
\hline
\end{tabular}

The prospects of diverting persistent increase in inflows of remittances to viable and productive investments which have growth-enhancing prowess is found non-existent in Nigeria. This study confirms the theoretical proposition of pessimistic view that migration does not benefits the home country but rather constitute loss of professionals and skilful personnel. The remittances from Nigeria's migrants do not contribute to growth in terms of brain gains but instead it drains the growth prospect of the country in the short and long-run by financing growth-inhibiting activities.

The growth benefits of an increase in inflows of remittances, an evidence of brain gains, to Nigeria's economy is non-existent in the short and long-run. This emerging empirical revelation is consistent with the studies of Lacheheb \& Ismail (2020), Uddin et al., (2020), Pradhan (2016), Sobiech (2015), Adarkwa (2015), Alkhathlan (2013) which establish that remittances retard and impede the growth prospects. It is an indication that remittances could not be relied as a positive driver that spur growth in Nigeria. It is clear that the inflow of 
Table 8: Short and Long-run Estimates of Nonlinear ARDL $(2,2,1,1,1,1,2,2,2)$

\begin{tabular}{|c|c|c|c|c|}
\hline Variable & Coefficient & Std. Error & $\mathrm{t}$-Statistic & Prob. \\
\hline \multicolumn{5}{|c|}{ short-run coefficients } \\
\hline$\Delta(\operatorname{LGRW}(-1))$ & 0.118 & 0.281 & 0.420 & 0.681 \\
\hline$\Delta(\mathrm{LLBF})$ & $1.136^{*}$ & 0.589 & 1.929 & 0.076 \\
\hline$\Delta(\operatorname{LLBF}(-1))$ & 0.032 & 0.526 & 0.061 & 0.952 \\
\hline$\Delta(\mathrm{LGCF})$ & -0.024 & 0.055 & -0.441 & 0.666 \\
\hline$\Delta\left(L R E M^{+}\right)$ & $-0.061 * * *$ & 0.012 & -5.312 & 0.000 \\
\hline$\Delta\left(\mathrm{LREM}^{-}\right)$ & $0.100 * * *$ & 0.032 & 3.073 & 0.009 \\
\hline$\Delta($ LFIND $)$ & $-1.217 * * *$ & 0.030 & -39.976 & 0.000 \\
\hline$\Delta(\mathrm{LINF})$ & $-0.029 * *$ & 0.011 & -2.518 & 0.026 \\
\hline$\Delta(\operatorname{LINF}(-1))$ & $-0.020 *$ & 0.011 & -1.859 & 0.086 \\
\hline$\Delta(\mathrm{LOPEN})$ & $0.036^{*}$ & 0.018 & 2.018 & 0.065 \\
\hline$\Delta(\operatorname{LOPEN}(-1))$ & -0.028 & 0.023 & -1.246 & 0.235 \\
\hline$\Delta(\mathrm{LEXR})$ & 0.033 & 0.021 & 1.621 & 0.129 \\
\hline$\Delta(\operatorname{LEXR}(-1))$ & 0.028 & 0.017 & 1.653 & 0.122 \\
\hline ECT(-1) & $-2.507 * * *$ & 0.042 & -59.502 & 0.000 \\
\hline \multicolumn{5}{|c|}{ Long-run Coefficients } \\
\hline LLBF & $0.440 * * *$ & 0.111 & 3.951 & 0.002 \\
\hline LGCF & 0.024 & 0.032 & 0.725 & 0.482 \\
\hline $\mathrm{LREM}^{+}$ & $-0.058 * * *$ & 0.003 & -18.126 & 0.000 \\
\hline LREM $^{-}$ & $-0.209 * * *$ & 0.009 & -23.057 & 0.000 \\
\hline LFIND & $-1.012 * * *$ & 0.027 & -37.099 & 0.000 \\
\hline LINF & $-0.012 *$ & 0.006 & -2.045 & 0.062 \\
\hline LOPEN & 0.008 & 0.012 & 0.701 & 0.496 \\
\hline LEXR & $0.013 *$ & 0.007 & 1.806 & 0.094 \\
\hline $\mathrm{C}$ & -0.040 & 0.964 & -0.042 & 0.967 \\
\hline
\end{tabular}

remittances have a deteriorating effect on economic growth and it confirms remittance curse effect on the level of economic growth (Lacheheb \& Ismail, 2020). It is observed that most of the previous studies on remittance-growth nexus in Nigeria find positive impact (John et al., 2020; Adeyi, 2015; Adeagbo \& Ayansola, 2014). This could be due to overestimation of their models as a result of covertly assuming linear and symmetric effect of remittance on growth.

The coefficient of labour input $(L L B F)$ is statistically significant in the linear model but its impact on economic growth is negative in the short-run. Meanwhile, the sign of the coefficient changes to positive in nonlinear model but insignificant. The labour input appears to be a long-run factor of growth in Nigeria. This is confirmed in both linear and nonlinear models. This follows the theoretical proposition of endogenous growth theory which emphasizes labour as a crucial factor of production that drives a long-run steady-state growth. Also, the capital input, measured by gross fixed capital formation, appears not to be an 
important factor of growth in both linear and nonlinear models. This is established in both short and long-runs.

The coefficient of financial development in the linear model is positive in the both short and long-runs but it is only significant in the long-run. However, the coefficient of financial development in the nonlinear model is significant but negative in short and long-run. These findings confirm the research outputs of Gazdar \& Cherif (2015), Ehigiamusoe \& Lean (2019), Adusei (2012) \& (2013), Loayza \& Ranciere (2006), Shen \& Lee (2006), and De Gregorio \& Guidotti (1995) which find financial development to be constituting drag to the growth by financing unproductive and growth-inhibiting activities in the economy. Similarly, the coefficients of inflation rate in all the models (linear and nonlinear) are significant but negative at conventional levels. These results are irrespective of whether short or long-runs. This shows that inflation in Nigeria has weakened the growth rate of economy. This is not surprising because the rates of inflation in most of the years are double-digit. It suggests that the rate of inflation in Nigeria might be above the threshold and desirable level (Khan \& Hanif, 2020; Khan \& Senhadji 2001). The data on inflation indicates that the average value is $19.35 \%$. This suggests that inflation appears to be killing productivity growth in Nigeria (Bawa \& Abdullahi, 2012). There is a need for stakeholders and policy makers to put in appropriate macroeconomic and stabilization policies to moderate inflation rate so as to reduce the price level in the economy to a desirable level that is favourable to productivity and growth-enhancing activities.

Also, the linear model suggest that trade openness is a major factor of economic growth in the short and long-run but the effect is only positive in the short-run and negative in the longrun. This may indicate that trade openness is beneficial to Nigeria's economy in the subsisting time but has the potential of hurting the economy if the necessary measures are not put in place to develop and depend less on other countries. Trade openness has tendency to constitute leakages to the economy which retard the growth process in the long-run. This could be attributed to the fact that trade openness might worsen the balance of trade deficits which has the likelihood of puncturing the economic growth. However, trade openness turns out not to be significant in the nonlinear model. Lastly, the short-run estimates of linear model reveal exchange rate has significant but negative influence on economic growth but the effect appears to be positive and significant in the long-run. Meanwhile, the exchange rate is found to be an insignificant factor of growth in the nonlinear model.

\subsubsection{Diagnostic tests}

Following the suggestions of extant studies (Olaniyi \& Adedokun, 2020; Olaniyi \& Oladeji, 2020; Mohanty, 2019; Ntembe et al., 2018), the short and long-run estimates of linear and nonlinear of error-correction version of ARDL are subjected to a series of robustness checks and diagnostic tests so as to ascertain the reliability of the estimates. Thus, the synopsis of residual diagnostics tests of normality, serial correlation, heteroskedascity and the Ramsey reset test for model specification are provided in Table 9. The results of Jarque-Bera statistics reveal that the error terms are normally distributed. Breusch-Godfrey serial correlation LM test indicates that the linear and nonlinear models are completely free from the problem of autocorrelation. Absence of specification error is also confirmed by Ramsey Reset test. Similarly, the results of Breusch-Pagan-Godfrey test authenticates the nonexistence of heteroskedasticity in the two models.

Furthermore, the stability of the parameters of linear and nonlinear error-correction version of ARDL is examined through the cumulative sum (CUSUM) and cumulative sum of 
squares (CUSUMSQ). CUSUM and CUSUMSQ confirm the stability of linear ARDL estimates (see Figure 3). This is affirmed as the lines are within the 5 percent critical boundaries (see Bahmani-Oskooee \& Ng, 2002). However, the nonlinear ARDL parameters are somewhat confirmed stable. CUSUM test indicates full stability while CUSUMSQ is only stable to an extent (see Figure 4).

Table 9: Diagnostic Tests of Linear and Nonlinear ARDL

Jarque Bera-Normality Test

\begin{tabular}{ccccc}
\multicolumn{2}{c}{ Linear } & ARD & & \multicolumn{2}{c}{ Nonlinear ARDL } \\
\cline { 1 - 2 } \cline { 5 - 6 } 1.327 & $(0.515)$ & & 2.494 & $(0.287)$ \\
3.376 & $(0.185)$ & & 2.852 & $(0.240)$ \\
1.058 & $(0.311)$ & & 1.489 & $(0.162)$ \\
21.904 & $(0.466)$ & & 22.716 & $(0.4179)$ \\
\hline
\end{tabular}

Breusch-Godfrey Serial Correlation LM Test:

Ramsey RESET Test

Note: the values in the brackets () are probaility values

\section{Source: Author's Computations}
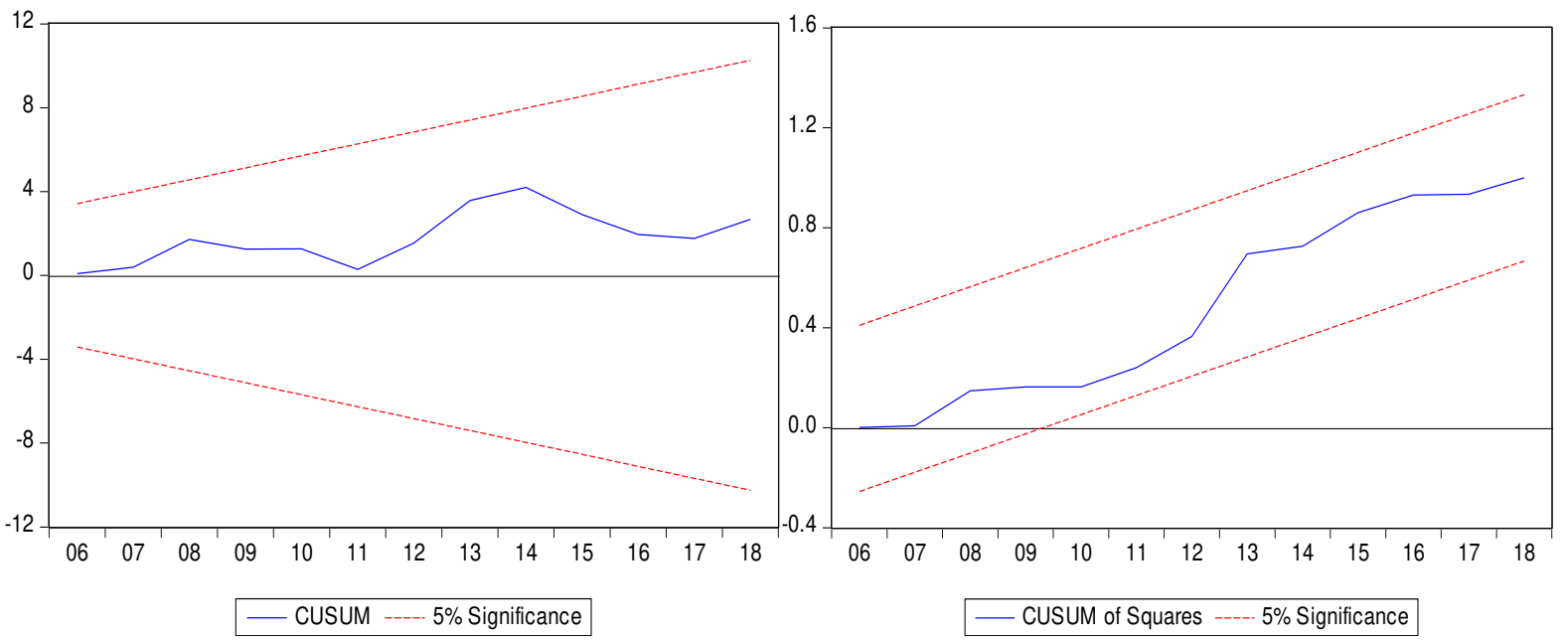

Figure 3: Stability test (CUSUM and CUSUMSQ) for linear ARDL (2, 2, 1, 1, 1, 1, 2, 2, 2) estimates

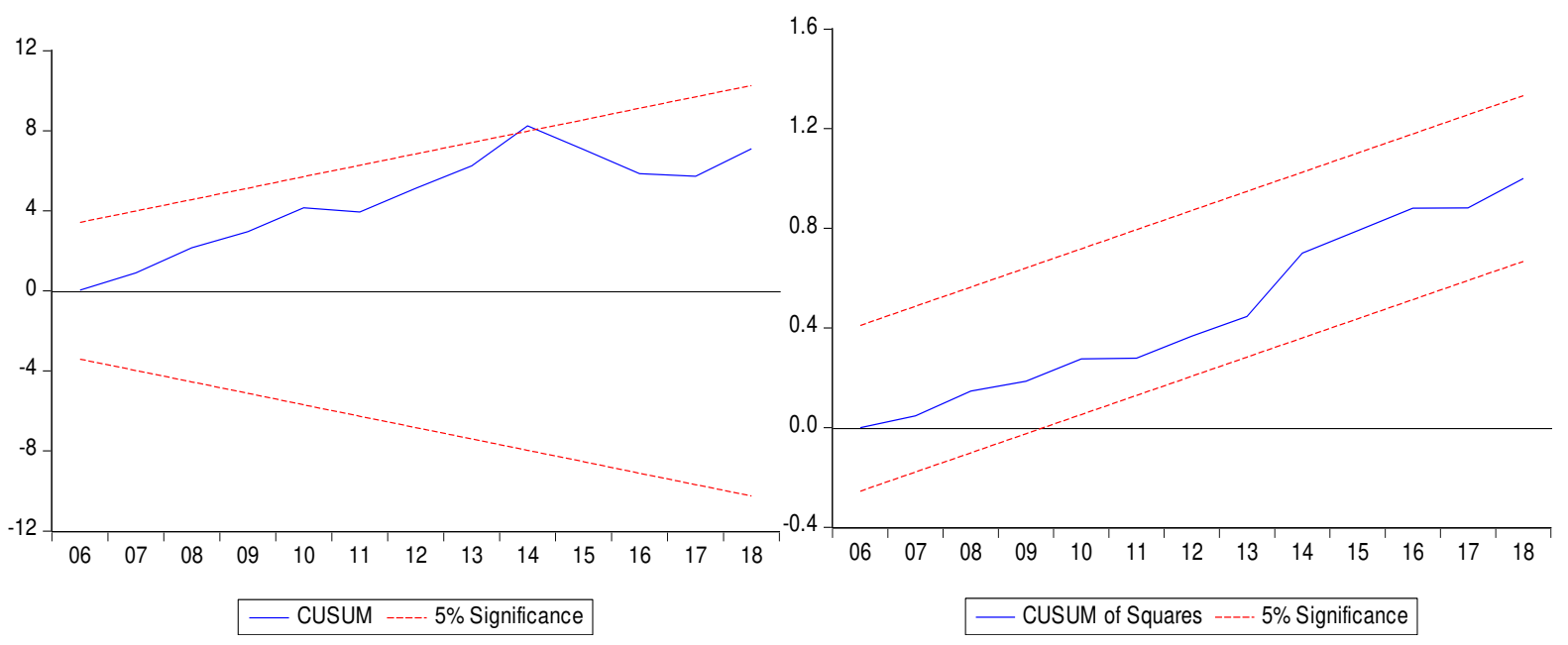

Figure 4: Stability test (CUSUM and CUSUMSQ) for nonlinear ARDL (2, 2, 1, 2, 2, 2, 2, 2) estimates 


\section{Conclusion}

There are intense debates on whether remittance inflows constitute brain gains or drains to the economies of the recipient countries in the subsisting empirical and theoretical literature. Extant studies on the remittance-growth nexus have been restricted to symmetric and linear effects. This assumption has been faulted that it does not accord well with realities. Linearity and symmetry are mere simplifying assumptions in econometric analyses which may not hold in real-life situations. This does not give room to empirically examine whether mass exodus of skilled and professional migrants produce brain gains or drains in their countries of births both in the short and long runs. In view of this assertion, we pioneer decomposing data on remittance inflows into positive components (brain gains) and negative components (brain drain). This allows us to examine asymmetric and nonlinear effect of remittance inflows on economic growth in Nigeria within the framework of nonlinear autoregressive distributed lag model. It is also argued in this study that prevalence of linear unit root tests in asymmetric and nonlinear models to determine stationarity properties is fundamentally faulty as they fail to account for asymmetries and nonlinearities in the series. The decision to utilize Nigeria's data is strategic and appropriate. One, there have been mass exodus of trained, skilled and professional workforce to other countries in search for greener pastures due to high unemployment rate, poor working and economic conditions in Nigeria. Two, Nigeria has been found to be the largest recipient of remittances in Africa. Three, there are asymmetric structures in the data distribution of remittance inflows to Nigeria.

The research outputs reveal there is no asymmetry in the effects of remittances on economic growth in Nigeria in the short-run while evidence of asymmetry in the long-run is found. The findings indicate that increases in the inflows of remittance (positive components) puncture economic growth prospect of the country in the short and long-runs. This confirms the nonexistence of brain gains in Nigeria and it supports the theoretical proposition of pessimistic view. It implies that the remittances received from Nigerians abroad are not channelled to investment, productive and growth-enhancing activities. This suggests that persistent increases in remittance inflows are majorly used to finance consumption and growth-inhibiting ventures. Thus, an increase in remittance inflows creates a disincentive to hard work in Nigeria. On the other hand, economic growth responds positively and significantly to declines in inflows of remittance in the short-run. The implication is that a fall in the inflow of remittance stimulates incentive to hard work and propel people to work hard which lead to a rise in the level of economic activity. Meanwhile, the long-run estimate of negative components of remittance also has a strong negative influence on economic growth. This shows that remittance in general (whether positive or negative components) does not stimulate economic activity in the longrun.

Based on the research outputs, it is apparent that remittance inflows from Nigerians abroad have appeared to have adverse effect on the economy. Hence, government and stakeholders should create appropriate policies and incentives that will be geared toward training and retaining the country's teaming population. There is also a need for the country to create an enabling environment to improve working and economic conditions so as to encourage skilled and professional workforce to stay back and contribute to economic growth prospects of the country. Lastly, the government should put in place strategies and policies to address the lingering unemployment and underemployment problems in Nigeria. This study has contributed to general discussions by incorporating asymmetries and nonlinearities into the 
remittance-growth nexus with emphasis on Nigeria. However, for robustness and comparative analysis other scholars are encouraged to carry out similar studies on asymmetric effect of remittance on economic growth for other countries.

\section{Declarations}

\section{Availability of data and materials:}

Data are readily available upon request.

\section{Competing interests:}

The authors declare that they have no competing interests

\section{Funding:}

The authors do not receive any financial assistance from any agency.

\section{Authors' contributions:}

This work is a joint idea of the authors. Author DOO conceived the idea, wrote the introduction and literature review while author $\mathrm{COO}$ did the analysis and interpretations of results, wrote the conclusion and the abstract. TAO wrote the methodology and sourced the data. All the authors read and approved the work.

\section{Acknowledgement:}

The authors are grateful to the anonymous referees and editorial crew of the journal for their extremely useful comments and suggestions to improve the quality of this article. Usual disclaimers apply

\section{References}

Adeagbo, O. \& Ayansola, O. A. (2014), Impact of remittances on development in Nigeria: Challenges and prospects, Journal of Sociology and Social Anthropology, 5:3, 311-318.

Adeyi, E. O. (2015). Remittances and economic growth: An empirical evidence from Nigeria and Sri Lanka. Basic Research Journal of Education Research and Review, 4(5), 9197.

Adusei, M. (2012). Financial development and economic growth: Is Schumpeter right. British Journal of Economics, Management \& Trade, 2(3), 265-278.

Adusei, M. (2013). Financial development and economic growth: Evidence from Ghana. The International Journal of Business and Finance Research, 7(5), 61-76.

Akonji D.R, \& Wakili AM (2013) The impact of net migrant remittance on economic growth: evidence from Nigeria, International Journal of Humanities and Social Sciences, 3(8)

Bahmani-Oskooee, M., \& Ng, R. C. W. (2002). Long-run demand for money in Hong Kong: an application of the ARDL model. International journal of business and economics, 1(2), 147-155

Bahmani-Oskooee, M. \& Nouira, R. (2019). On the impact of exchange rate volatility on Tunisia's trade with 16 partners: an asymmetry analysis. Economic Change and Restructuring https://doi.org/10.1007/s10644-019-09250-y

Banerjee, A., Dolado, J., \& Mestre, R. (1998). Error-correction mechanism tests for cointegration in a single-equation framework. Journal of Time Series Analysis, 19(3), 267-283. 
Bawa, S., \& Abdullahi, I. S. (2012). Threshold effect of inflation on economic growth in Nigeria. CBN Journal of Applied Statistics, 3(1), 43-63.

Beijer G. 1970. International and National Migratory Movements. International Migration VIII:93-109.

Cazachevici, A., Havranek, T., \& Horvath, R. (2020). Remittances and economic growth: A meta-analysis. World Development, 134,

105021. https://doi.org/10.1016/j.worlddev.2020.105021

Chowdhury M (2016). Financial development, remittances and economic growth: evidence using dynamic panel estimation. J. Appl Econ Res 10(1):35-54

Cooray A (2012) Migrant remittances, financial market development and the government ownership of banks: evidence from a group of non-OECD economies. Journal of International Financial Markets, Institutions and Money, 22(4): 936-957

De Gregorio, J., \& Guidotti, P. E. (1995). Financial development and economic growth. World development, 23(3), 433-448.

Domingues Dos Santos, M. \& Postel-Viney, F (2003). Migration as a source of growth: The perspective of a developing country. Journal of Population Economies 16(1), 161-75.

Dong, D., Gozgor, G., Lu, Z., \& Yan, C. (2020). Personal consumption in the United States during the COVID-19 crisis. Applied Economics, 1-6. https://doi.org/10.1080/00036846.2020.1828808

Ehigiamusoe, K. U., \& Lean, H. H. (2019). Influence of real exchange rate on the financegrowth nexus in the West African region. Economies, 7(1), 23.

Gazdar, K., \& Cherif, M. (2015). Institutions and the finance-growth nexus: Empirical evidence from MENA countries. Borsa Istanbul Review, 15(3), 137-160.

Iheke, O.R. (2012), The Effect of Remittances on the Nigerian Economy. International Journal of Development and Sustainability, 1(2), 614-621.

Imai, K.S., Gaiha, R., Ali. A.,\& Kaicker, N. (2014) Remittances, growth and poverty: New evidence from Asian countries, Journal of Policy Modeling, http://dx.doi.org/10/1016/j.jpolmod.2014.01.009.New evidence from Asian countries.

IOM (2014). International Organization for Migration (IOM) World Migration Report, Geneva, Switzerland.

Javid M, Arif U, Abdul Q (2012) Impact of remittances on economic growth and poverty, Academic Research International, 2(1).

John, J. I., Orok, A. B., \& Udoka, C. O. (2020). Migrant remittances and economic growth: the Nigerian perspective. International Journal of Scientific Engineering and Science, 4(1), 52-57, 2020

Kadozi, E. (2019). Remittance Inflows and Economic Growth in Rwanda doi.org/10.1016/j.resglo.2019.100005

Kapetanios, G., Shin, Y., \& Snell, A. (2003). Testing for a unit root in the nonlinear STAR framework. Journal of Econometrics, 112(2), 359-379.

Kapetanios, G., \& Shin, Y. (2008). GLS detrending-based unit root tests in nonlinear STAR and SETAR models. Economics Letters, 100(3), 377-380.

Karikari NK, Mensah S, \& Harvey SK (2016) Do remittances promote financial development in Africa? Springer Plus 5: 1-21.DOI 10.1186/s40064-016-2658-7

Khan A, Azam M (2011) Workers' Remittances and Economic Growth: Evidence from Azerbaijan and Armenia, Global J of Human Social Science, 11(7)

Khan, M., \& Hanif, W. (2020). Institutional quality and the relationship between inflation and economic growth. Empirical Economics, 58(2), 627-649. 
Khan, M. S., \& Ssnhadji, A. S. (2001). Threshold effects in the relationship between inflation and growth. IMF Staff papers, 48(1), 1-21.

Kisswani, A. M. and Kisswani K. M. 2019. Modelling the employment-oil price nexus: a nonlinear cointegration analysis for the U. S. market. Journal of International Trade \& Economic Development, 1-17.

Koay YY, \& Choong C.K. (2013) The nexus between worker remittances and economic growth in Malaysia, Prosiding Perkem VIII,JILID 1,Pp.507-515, ISSN:2231-962X

Kratou, H., \& Gazdar, K. (2015). Addressing the effect of workers' remittance on economic growth: evidence from MENA countries. International Journal of Social Economics. 43(1), 51-70. https://doi.org/10.1108/IJSE-08-2013-0189

Kumar RR (2013) Remittances and economic growth: a study of Guyana. Econ Syst 37(3):462-472

Lacheheb, Z., \& Ismail, N. W. (2020). The impact of remittance on economic growth in low and middle income countries. Sciences, 9(2), 61-70.

Loayza, N. V., \& Ranciere, R. (2006). Financial development, financial fragility, and growth. Journal of Money, Credit and Banking, 38(4), 1051-1076

Lewis W,A. (1954). Economic Development with Unlimited Supplies of Labour. Manchester School of Economic and Social Studies 22:139-91

Lipton M (1980) Migration from the rural areas of poor countries: the impact on rural productivity and income distribution. World Dev 8(1):1-24.

Lowel, L.B \& Findlay, A.M. (2001). Migration of highly skilled persons from developing countries: Impact and policy responses: synthesis report, International migration papers, No.44, Geneva: International labor office (Draft synthesis report).

Meo, M. S., Chowdhury, M. A. F., Shaikh, G. M., Ali, M., \& Masood Sheikh, S. (2018). Asymmetric impact of oil prices, exchange rate, and inflation on tourism demand in Pakistan: new evidence from nonlinear ARDL. Asia Pacific Journal of Tourism Research, 23(4), 408-422.

Mohanty, R. K. (2019). An empirical investigation of twin deficits hypothesis: Evidence from India. Journal of Quantitative Economics, 17(3), 579-601.

Naiditch, C., Tomini, A. \& Lakhdar, B. C. (2015), Remittances and Incentive to Migrate: An Epidemic Approach of Migration. Science Direct International Economics 142.118135

Ntembe, A., Amin, A.A. \& Tawah, R. (2018). Analysis of public investments and economic growth in Cameroon. Journal of Economics and Finance, 42(3), 591-614

Olaniyi, C. (2019). Asymmetric information phenomenon in the link between CEO pay and firm performance. Journal of Economic Studies. 46(2), 306-323.

Olaniyi, C. O., \& Adedokun, A. (2020). Finance-institution-growth trilogy: time-series insights from South Africa. International Journal of Emerging Markets. https://doi.org/10.1108/IJOEM-05-2019-0370

Olaniyi, C. O. \& Oladeji, S. I. (2020). Interplay between financial sector and institutional framework in the economic growth process of Kenya. Journal of Public Affairs. https://doi.org/10.1002/pa.2562 
Olaniyi, C. O., \& Olayeni, O. R. (2020). A new perspective into the relationship between CEO pay and firm performance: evidence from Nigeria's listed firms. Journal of Social and Economic Development, 22(2), 250-277. https://doi.org/10.1007/s40847-020-00103-3

Olayungbo D.O., \& Ahmod Q. (2019). Remittances, Financial Development and Economic Growth in sub-Saharan African countries: evidence from a PMG-ARDL approach, https://doi.org/10.1186/s40854-019-0122-8. Financial Innovation 5(9),1-25. Springer.

Otero, J., \& Smith, J. (2017). Response surface models for OLS and GLS detrending-based unit-root tests in nonlinear ESTAR models. The Stata Journal, 17(3), 704-722.

Pesaran M. H, Shin Y, Smith, R. J. (2001) Bound testing approaches to the analysis of level relationships. J Appl Econ 16:289-326

Pradhan, K. C. (2016). Does remittance drive economic growth in emerging economies: Evidence from FMOLS and Panel VECM. Theoretical \& Applied Economics, 23(4).

Rubenstein H (1992) Migration. Development and remittances in rural Mexico. Int Migr 30(2):1992.

Russell S., S. 1992. Migrant Remittances and Development. International Migration 30(4), 267-287.

Shahbaz, M., Van Hoang, T. H., Mahalik, M. K., \& Roubaud, D. (2017). Energy consumption, financial development and economic growth in India: New evidence from a nonlinear and asymmetric analysis. Energy Economics, 63, 199-212.

Shahbaz, M., Khraief, N., \& L Czudaj, R. (2020). Renewable energy consumption-economic growth nexus in G7 countries: New evidence from a nonlinear ARDL approach. Economics Bulletin, 40(4), 2828-2843

Shen, C. H. and Lee, C. C. (2006). Same financial development yet different economic growth: why? Journal of Money, Credit and Banking, 38(7), 1907-1944.

Shin, Y., Yu, C., and Greenwood-Nimmo. (2014). Modelling asymmetric cointegration and dynamic multi-pliers in a nonlinear ARDL framework. In Festschrift in Honor of Peter Schmidt, edited by W. C. Horrace and R. C. Sickles. New York (NY): Springer Science $\&$ Business Media.

Sobiech .I(2015) Remittances, finance and growth: does financial development foster remittances and their impact on economic growth?, FIW Working Paper Series, No 158

Sibindi A.B. (2014). Remittances, financial development and economic growth: empirical evidence from Lesotho. Journal of Governance and Regulation, 3(4):116-124

Siddique A, Selvanathan EA, Selvanathan S (2010) Remittances and economic growth: empirical evidence from Bangladesh, India and Sri Lanka. The university of Western Australia. Discussion paper 10.27.

Stark, O. \& Wang, Y. (2002). Inducing human capital formation: Migration as a substitute for subsidies. Journal of Development Economics 86:29-46.

Todaro, M.P. (1969). A model of labor migration and urban unemployment in less developed countries. Am Econ Rev 59:138-148.

Todaro, M. P. \& Smith, S.C. (2015). Economic Development. $12^{\text {th }}$ Edition. Pearson.

Uddin, M. N., Uddin, M. J., Uddin, J., \& Ahmmed, M. (2020). Remittances and Economic Growth Tie in Selected South Asian Countries: A Panel Data Analysis. International Journal of Financial Research, 11(1), 197-205.

World Bank (2014). International bank for reconstruction and development, Washington, D.C 20433 USA www.worldbank.org.

World Development Indicator (2019). The World Bank 1818 H Street N.W. Washington, D.C, 20433. USA

World Bank (2020). International bank for reconstruction and development, Washington, D.C 20433 USA www.worldbank.org. 
Yannik, B.N \& Roger, T.N. (2020). Remittances, financial inclusion and income inequality in Africa. University of DSCHANG, Atlantique Assurance Cameroun IARDT. https://mpra.ub.uni-muechen.de/99684/MPRA Paper No.99684. 


\section{Figures}

Nigeria was the highest recipient of remittances in 2019 - $\$$ billions

\begin{tabular}{l|l|}
\hline Nigeria & $\mathbf{2 3 . 8}$ \\
\hline Ghana & $\mathbf{3 . 5}$ \\
\hline Kenya & $\mathbf{2 . 8}$ \\
\hline Senegal & $\mathbf{2 . 5}$ \\
\hline DR Congo & $\mathbf{1 . 8}$ \\
\hline Zimbabwe & $\mathbf{1 . 7}$ \\
\hline Uganda & $\mathbf{1 . 3}$ \\
\hline South Sudan & $\mathbf{1 . 3}$ \\
\hline Mali & $\mathbf{1}$ \\
\hline South Africa & $\mathbf{1}$ \\
\hline
\end{tabular}

2uartz $\mid$ qz.0om | Data: World Bank

\section{Figure 1}

Remittance flows to selected sub-Saharan African countries. Source: World Bank 2020. 
LREM POS

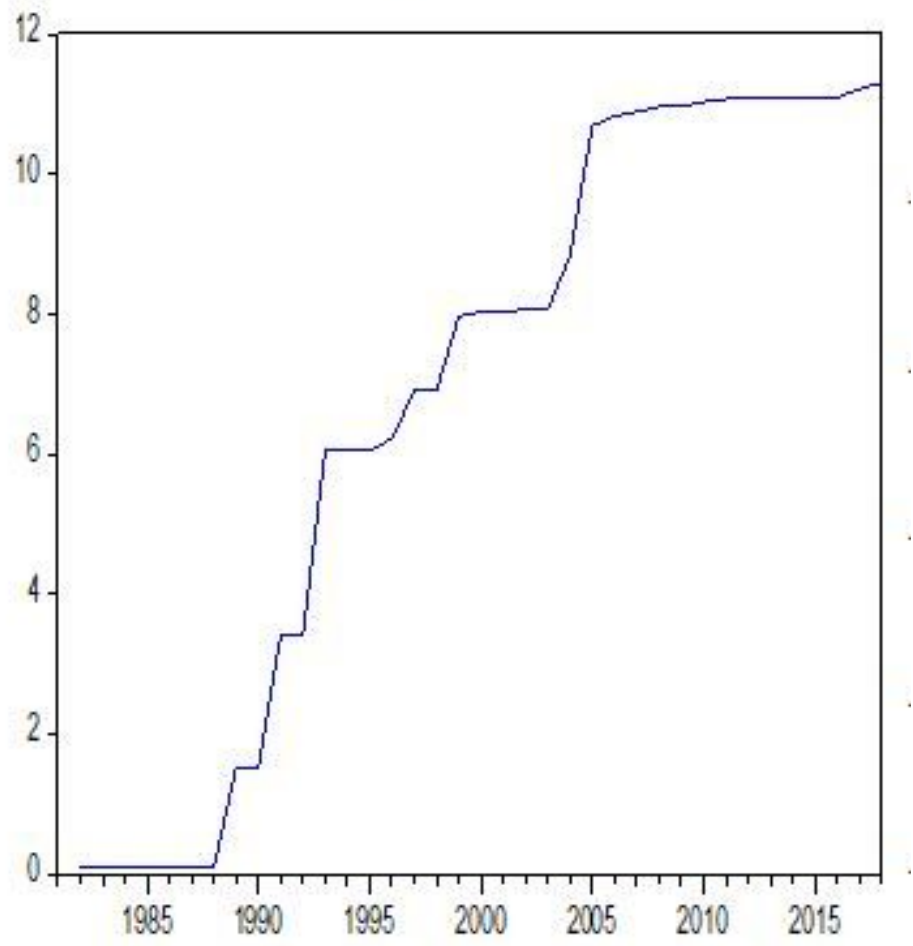

Figure 2

Positive component of Remittances

LREM_NEG

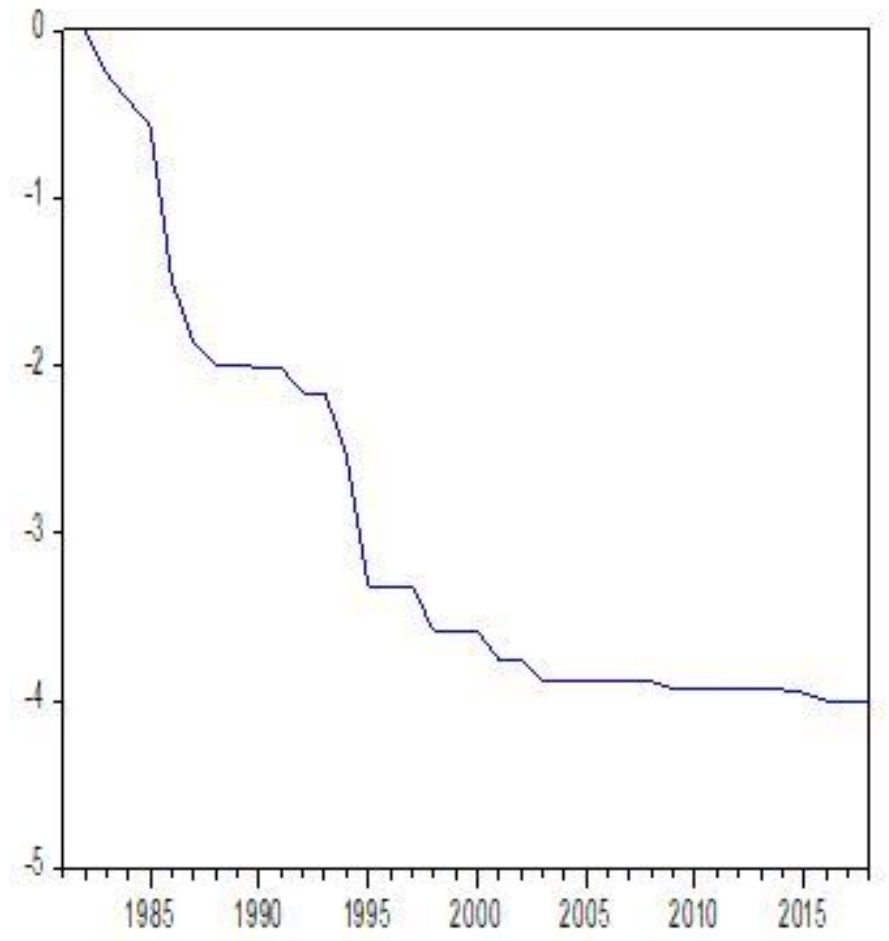

Figure 3 
Negative component of Remittances

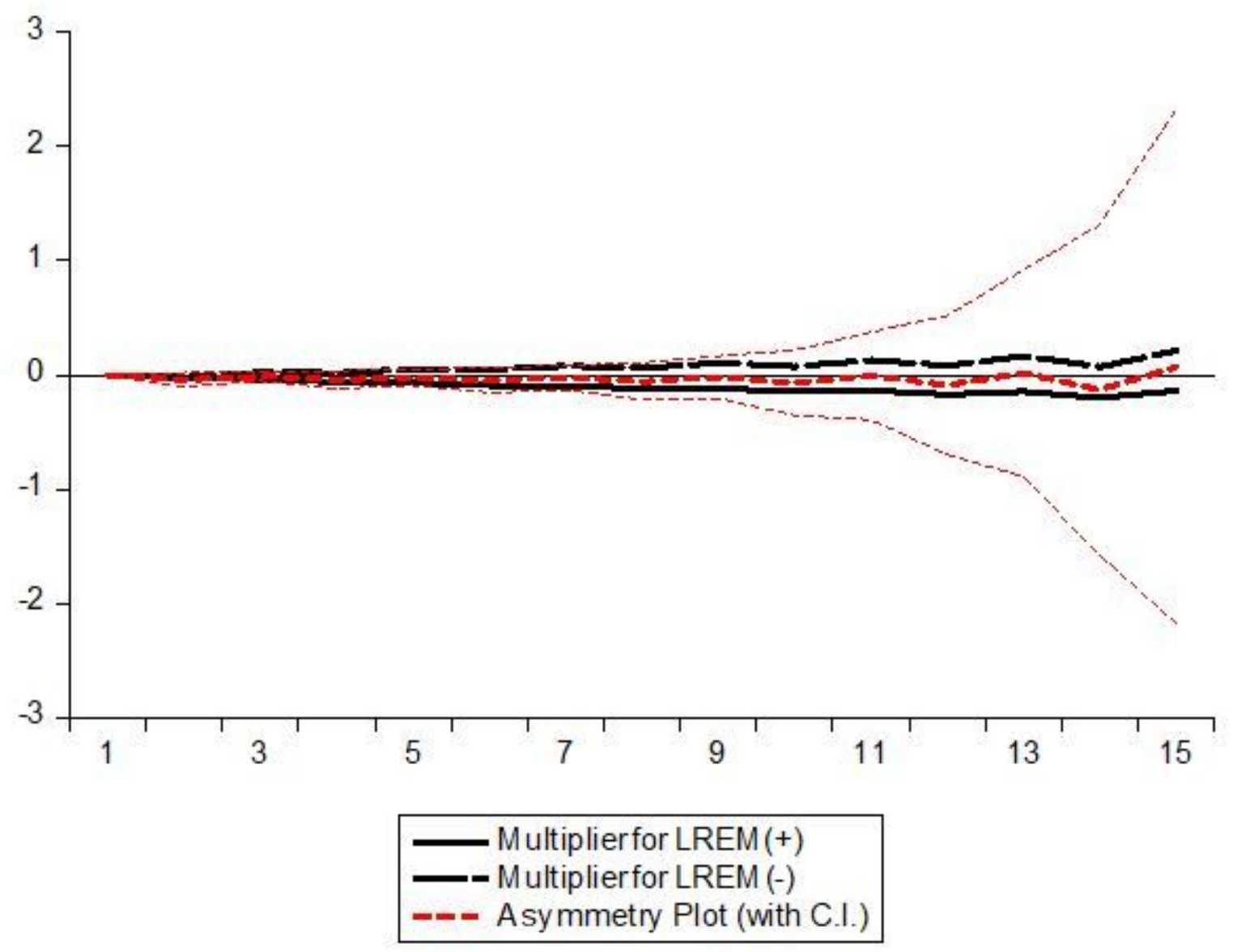

\section{Figure 4}

The Graph of Nonlinear ARDL Dynamic Multiplier
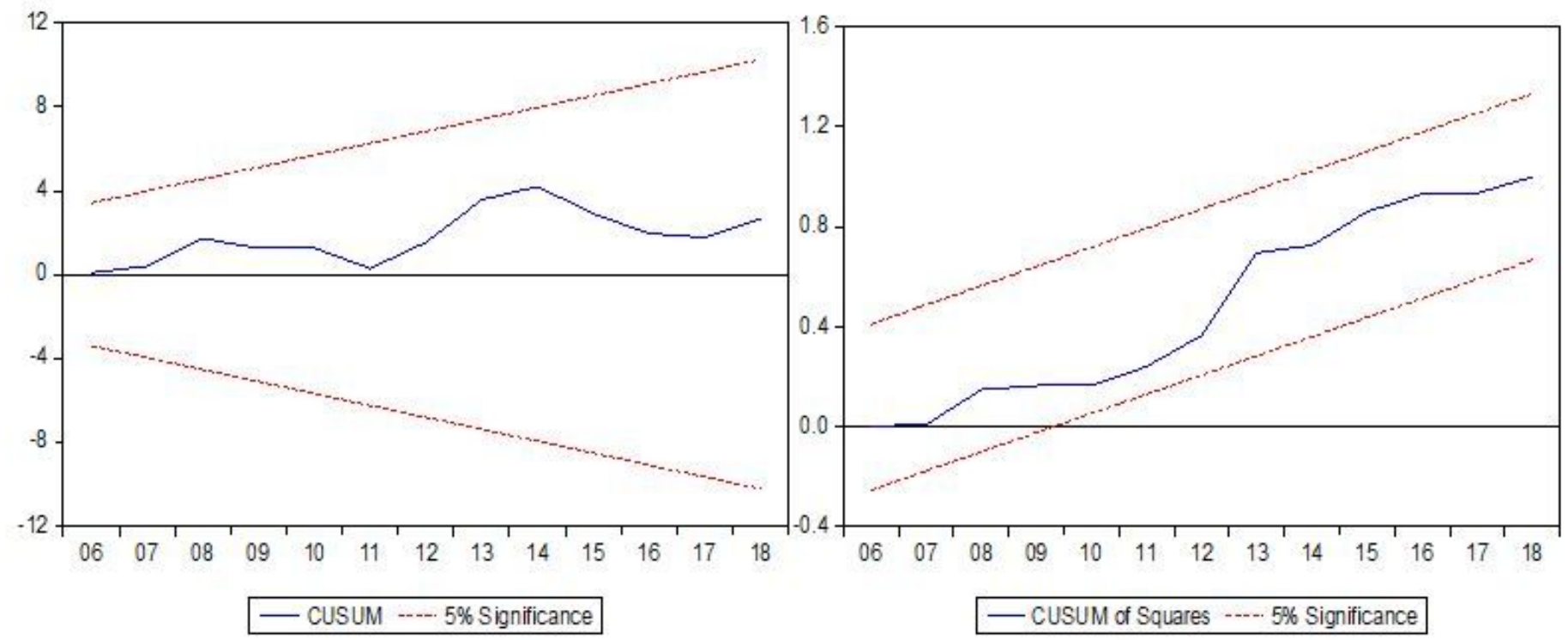

Figure 5

Stability test (CUSUM and CUSUMSQ) for linear ARDL $(2,2,1,1,1,1,2,2,2)$ estimates 

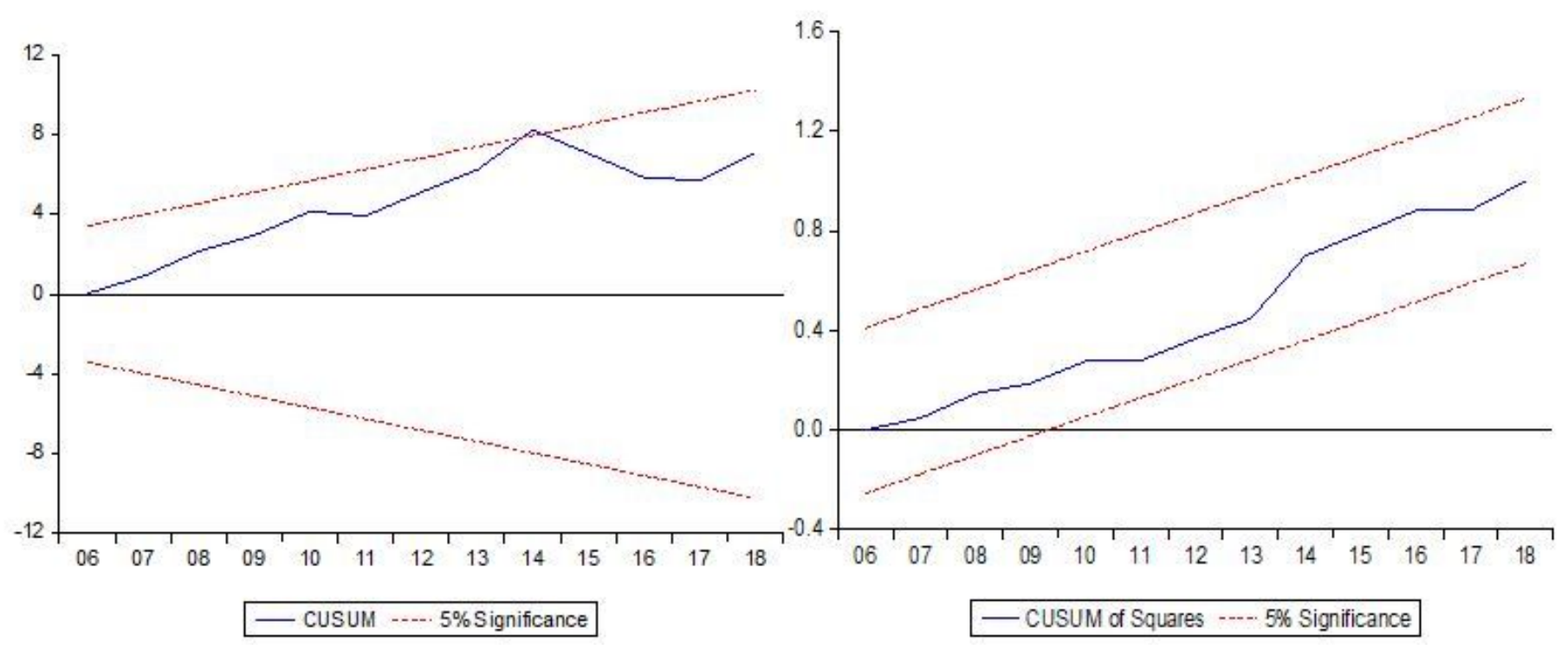

\section{Figure 6}

Stability test (CUSUM and CUSUMSQ) for nonlinear ARDL $(2,2,1,2,2,2,2,2)$ estimates 